\title{
Guiclupea superstes, gen. et sp. nov., the youngest ellimmichthyiform (clupeomorph) fish to date from the Oligocene of South China
}

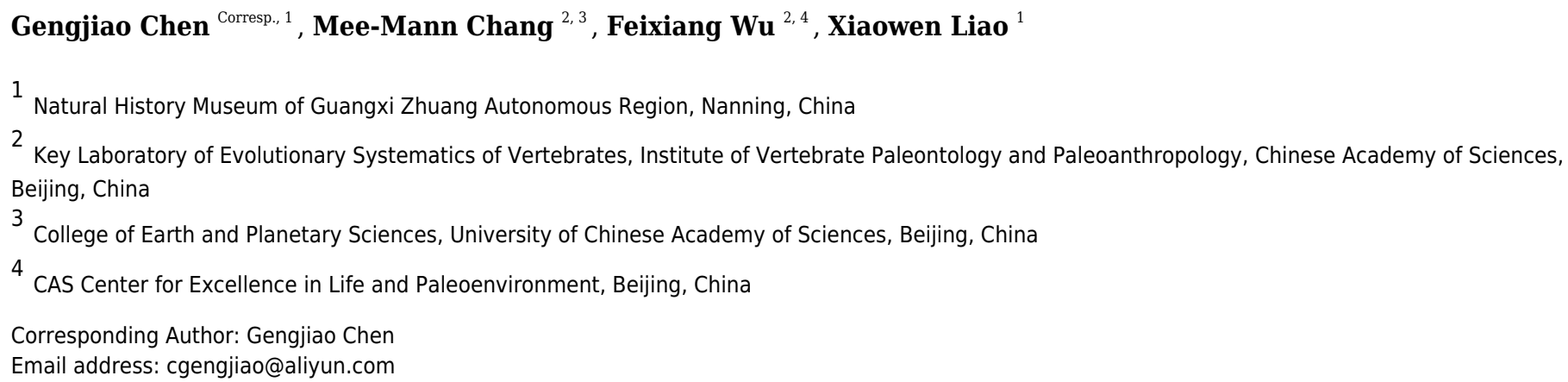

A new ellimmichthyiform, Guiclupea superstes, gen. et sp. nov., from the Oligocene Ningming Formation of Ningming Basin, Guangxi Zhuang Autonomous Region, South China is described herein. With relatively large body size, parietals meeting at the midline, anterior ceratohyal with a beryciform foramen in the center, a complete predorsal scutes series of very high number and about equally-size scutes with radiating ridges on dorsal surface, first preural centrum unfused with first uroneural but fused with the parhypural, and first ural centrum of roughly the same size as the preural centrum, Guiclupea superstes cannot be assigned to the order Clupeiformes. The phylogenetic analyses using parsimony and Bayesian inference methods with Chanos/Elops as outgroup respectively suggests that the new form is closer to ellimmichthyiform genus Diplomystus than to any other fishes, although there are some discrepancies between the two criteria and different outgroups used. It shares with Diplomystus the high supraoccipital crest, pelvic-fin insertion in advance of dorsal fin origin, and the number of predorsal scutes more than 20. The new form represents the youngest ellimmichthyiform fish record in the world. Its discovery indicates that the members of the Ellimmichthyiformes had a wider distribution range and a longer evolutional history than previously known. 
1 Guiclupea superstes, gen. et sp. nov., the youngest ellimmichthyiform (clupeomorph) fish to

2 date from the Oligocene of South China

3 Gengjiao $\mathrm{CHEN}^{1 *}$, Mee-Mann $\mathrm{CHANG}^{2,3}$, Feixiang WU²,4, Xiaowen $\mathrm{LIAO}^{1}$

$4{ }^{1}$ Natural History Museum of Guangxi Zhuang Autonomous Region, Nanning 530012, China;

$5 \quad{ }^{2}$ Key Laboratory of Evolutionary Systematics of Vertebrates, Institute of Vertebrate

6 Paleontology and Paleoanthropology, Chinese Academy of Sciences, Beijing 100044, China;

$7 \quad{ }^{3}$ College of Earth and Planetary Sciences, University of Chinese Academy of Sciences, Bejing

$8 \quad$ 100049, China

$9{ }^{4}$ CAS Center for Excellence in Life and Paleoenvironment, Beijing 100044, China;

*Corresponding author: cgengjiao@aliyun.com

Abstract A new ellimmichthyiform, Guiclupea superstes, gen. et sp. nov., from the Oligocene

Ningming Formation of Ningming Basin, Guangxi Zhuang Autonomous Region, South China is described herein. With relatively large body size, parietals meeting at the midline, anterior ceratohyal with a beryciform foramen in the center, a complete predorsal scutes series of very high number and about equally-size scutes with radiating ridges on dorsal surface, first preural centrum unfused with first uroneural but fused with the parhypural, and first ural centrum of roughly the same size as the preural centrum, Guiclupea superstes cannot be assigned to the order Clupeiformes. The phylogenetic analyses using parsimony and Bayesian inference methods with Chanos/Elops as outgroup respectively suggests that the new form is closer to ellimmichthyiform genus Diplomystus than to any other fishes, although there are some discrepancies between the two criteria and different outgroups used. It shares with Diplomystus the high supraoccipital crest, pelvic-fin insertion in advance of dorsal fin origin, and the number 
24 of predorsal scutes more than 20 . The new form represents the youngest ellimmichthyiform fish

record in the world. Its discovery indicates that the members of the Ellimmichthyiformes had a wider distribution range and a longer evolutional history than previously known.

Keywords Ellimmichthyiforms, Oligocene, southern China, phylogeny, paleobiology

\section{Introduction}

The Ellimmichthyiformes is one of the two major clades of the Clupeomorpha (Nelson et al., 2016). The Recent Clupeomorpha is represented only by the order Clupeiformes, which is amongst the most economically important fish species for food, and contains both fossil and extant herrings, anchovies, and other relatives (Lavoué et al, 2014). The order

Ellimmichthyiformes is an extinct cosmopolitan clade (Nelson et al., 2016), established by Grande in 1982. It initially included only a single family Paraclupeidae (see Chang \& Grande 1997; Hay et al., 2007) with only two genera-Diplomystus and Ellimmichthys, diagnosed by bearing a series of predorsal scutes expanding laterally then taking a subrectangular-shape, and lacking some derived characters of the Clupeiformes, e.g., presence of recessus lateralis, parietal bones completely separated by the supraoccipital, and loss of the 'beryciform' foramen in anterior ceratohyal (Grande, 1982, 1985). Since the establishment of Ellimmichthyiformes, especially in the last two decades, many new and previously known genera and species have been either added or moved to this order (Silva Santos, 1990, 1994; Bannikov \& Bacchia, 2000; Chang \& Maisey, 2003; Poyato-Ariza \& García-Garmilla, 2000; Forey et al., 2003; Hay et al., 2007; Alvarado-Ortega \& Ovalles-Damián 2008; Khalloufi et al., 2010; Newbrey et al 2010; Murray \& Wilson, 2011, Malabarba et al., 2004; Bannikov, 2015; Vernygora \& Murray, 2015; Murrey et al., 2016; Alvarado-Ortega \& Melgarejo-Damián. 2017; Polck et al., 2020; etc), 
47 although some of them have the predorsal scutes pattern only partially in agreement with or

completely disagree with this order-level character, e.g., Ellimma branneri, whose anterior predorsal scutes are longer than broad; Scutatospinosus itapagipensis and Codoichthys carnavalii, without any subrectangular predorsal scutes at all, completely disagree with the order-level character. Along with the increasing membership of this order, several families were erected, and the interest in the definition, classification, and intra-relationship of the group has been increasing (Bannikov \& Bacchia, 2000; Chang \& Maisey, 2003; Zaragüeta-Bagils, 2004; Alvarado-Ortega et al., 2008; Murray \& Wilson, 2013; Figueiredo \& Ribeiro 2016; Vernygora et al., 2016; Marramà \& Carnevale 2017; Boukhalfa et al., 2019; Vernygora \& Murray, 2020; etc), although no definitive consensus has been reached on these issues. The main differences among the results of previous studies are the relationship of Armigatus and Diplomystus. Some analyses suggested that Armigatus is sister to Diplomystus (Chang \& Maisey, 2003, Murray \& Wilson, 2013 whereas others suggested that Armigatus is in a more basal (Forey, 2004; Figueiredo \& Ribeiro 2016) or derived (Vernygora \& Murray, 2016; Marramà \& Carnevale 2017; Boukhalfa et al., 2019) position than Diplomystus, or Armigatus is not an ellimmichthyiform member (Zaragüeta-Bagils, 2004). And still others suggested that Ornategulum may or may not be an ellimmichthyiform (Murrey \& Wilson, 2013; Marrama et al., 2018; Figuereido \& Ribeiro 2017; Boukhalfa et al., 2019). To date, the reported members of the group have reached 21 genera and 38 species at least, ranging from the Early Cretaceous to middle Eocene marine and non-marine strata of Eastern Asia, Middle East, North and South America, Africa, and Europe (Figure 1). No ellimmichthyiform fish from strata younger than the Eocene has ever been reported. Accordingly, it was believed that the ellimmichthyiforms finally became extinct after the middle Eocene. However, recently, an Oligocene ellimmichthyiform fish was discovered from the non-marine 
deposits of Ningming Basin, Guangxi Zhuang Autonomous Region, South China. Therefore, this new ellimmichthyiform fish represents the youngest record. This discovery not only extends the spatial and temporal distribution of ellimmichthyiforms, but also sheds new light on our understanding of the evolutionary history and paleobiogeography of the order. Herein we describe the new form, perform a phylogenetic analysis of the Ellimmichthyiformes, and discuss its taxonomic position and paleobiographical implications.

\section{Abbreviations}

Institutional Abbreviation —IVPP, Institute of Vertebrate Paleontology and

Paleoanthropology, Chinese Academy of Sciences, Beijing, China. NHMG, Natural History Museum of Guangxi Zhuang Autonomous Region, China.

Anatomical Abbreviations - aa, angulo-articular; ach, anterior ceratohyal; as, autosphenotic; br, branchiostegal rays; cl, cleithrum; cor, coracoid; cs, caudal scute; d, dentary; ect, ectopterygoid; en, epineural; enpt, entopterygoid; ep, epural; epl, epipleural; fr, frontal; h, hypural; hy, hyomandibula; io, infraorbital; iop, interopercle; la, lacrimal; le, lateral ethmoid; met, metapterygoid; ms, mesethmoid; msc, mandibular sensory canal; mx, maxilla; ns, neural spine; op, opercle; pa, parietal; pch, posterior ceratohyal; pcl, postcleithrum; pd, predorsal bones (supraneurals); ph, parhypural; pmx, premaxilla; pop, preopercle; pr, pleural rib; ps, parapophysis; pt, posttemporal; pto, pterotic; pu, preural centrum; q, quadrate; ra, retroarticular; sc, scapula; scl, supracleithrum; scr, sclerotic bone; so, supraorbital; sop, subopercle; smxa, anterior supramaxilla; smxp, posterior supramaxilla; sp, sphenotic; spo, supraoccipital; sy, symplectic; u, ural centrum; uh, urohyal; un, uroneural; vo, vomer; vs, ventral scutes.

\section{Materials and Methods}

The fossil specimens except NHMG 038777, that are described herein, include both 
93 articulated skeletons and detached bones and were collected from the outcrops about $2.5 \sim 3.5 \mathrm{~km}$

94 west of Ningming County, Guangxi, South China (Figure 1), about $40 \mathrm{~km}$ away from the

95 boundary of China and Vietnam and about $120 \mathrm{~km}$ northwest of the South China Sea. They are

96 housed in the NHMG now. The fossil-bearing strata is positioned in the middle-upper part of the

97 Second Member of the Yongning Group (Bureau of Geology and Mineral Resources of Guangxi

98 Zhuang Autonomous Region, 1985), or Ningming Formation (Li et al., 1995), which is a set of

99 fossiliferous lacustrine sediments dominated by light-gray, yellowish mudstones, occasionally

100 containing fine sand grains. The deposits also contain a variety of cyprinid and a few siluriform

101 and perciform fishes, and a large number of plant macrofossils (Chen et al., 2018). No

102 isotopically datable volcanic material was found at the locality. The geological age of the

103 Ningming Formation, according to palynologists (Wang et al., 2003), is Oligocene.

104 Paleobotanists concurred after they had studied macrofossil plant from the same strata (Li et al.,

105 2003; Shi et al., 2010, 2012, 2014; Wang et al., 2014; Dong et al., 2017; Ma et al., 2017; etc).

106 We applied this geological age also when we studied Huashancyprinus robustispinus

107 (Cyprinidae, Cypriniformes) from the same locality and horizon (Chen \& Chang, 2011) and

108 adopt it herein. NHMG 038777 is a disarticulated dentary collected from the Yongning

109 Formation of Santang, Nanning basin, Guangxi. The geological age of Yongning Formation is

110 the Oligocene (Zhao, 1983, 1993; Quan et al., 2012)

111 Fossil fish materials were prepared mechanically with steel needles of different sizes under a

112 binocular microscope. Line drawings were done based on the observations of the fossils under an

113 Olympus SZ61 microscope and the photos.

114 The taxonomic terminology and the methods of counting and measurement used here follow

115 Grande (1982) and Forey et al. (2003). The descriptions of gill rakers follow Bornbusch \& Lee 
116 (1992). Specimens used for comparison include: 1) Paraclupea chetungensis Sun 1956,

117 including IVPP V816, V2986.2, V3002.1, 5-8, 10, 12, 15, 19, from the Lower Cretaceous

118 Chawan Formation, eastern China; 2) Diplomystus shengliensis Zhang et al. 1985, including

119 SOF 790001, SOF 790002, and SOF 790003, and 3) Knightia bohaiensis Zhang et al. 1985,

120 including SOF 790003, from the top of series 4 to the bottom of series 3 of the Shahejie

121 Formation, Middle Eocene, East China; and 4) dried skeleton and disarticulated bones of Ilisha

122 elongate, NHMG 038785, collected from Nanning Dancun Market.

123 The electronic version of this article in portable document format will represent a published

124 work according to the International Commission on Zoological Nomenclature (ICZN), and hence

125 the new names contained in the electronic version are effectively published under that Code from

126 the electronic edition alone. This published work and the nomenclatural acts it contains have

127 been registered in ZooBank, the online registration system for the ICZN. The ZooBank Life

128 Science Identifiers (LSIDs) can be resolved and the associated information viewed through any

129 standard web browser by appending the LSID to the prefix http://zoobank.org/. The LSID for

130 this publication is: urn : lsid: zoobank.org: pub: 99B7F0EE-3695-4178-9606-

131

132

133

134

135

136

137

138

1CD8BD90316C. The online version of this work is archived and available from the following digital repositories: PeerJ, PubMed Central, and CLOCKSS.

The phylogenetic analyses are based on a data matrix (see Appendix 1S-3S) consisting of 55 morphological characters and 40 taxa, including three Recent clupeiform species (Denticeps clupeoides, Chirocentrus dorab, and Odaxothrissa vittata (the first one is the only extant member of the Denticipitoidei; the latter two represent the Clupeoidei), a gonorynchiform or elopomorph (Chanos chanos or Elops saurus, being used as outgroup alternatively to polarize the characters and root the tree), the enigmatic fossil Ornategulum sardinioides Forey 1973, and 
139 our new form (to test its position within the Clupeomorpha). Characters are adopted mainly from 140 Chang \& Maisey (2003), and Murray \& Wilson (2013).

141 The analyses use both parsimony and Bayesian inference methods, for both methods have 142 advantages and disadvantages for morphological data (Bai et al., 2020). The parsimony analyses

143 144 145 146 147 148 149 150 151 152 153 154 155 156 157 158 159 160 161 were performed with TNT 1.5 (Goloboff et al., 2008), using the Traditional Search method with 1000 replicates and tree bisection and reconnection (TBR) swapping algorithm. All characters are unordered and equally weighted. The most parsimonious trees (MPTs) generated by the analysis were used to construct a strict consensus tree. Tree length, consistency index (CI), retention index $(\mathrm{RI})$, Bremer support and bootstrap values were then calculated for the strict consensus tree.

Bayesian analyses were conducted by MrBayes 3.1.2 (Ronquist \& Huelsenbeck, 2003). For the substitution models, the Mkv model was used with an assumption of gamma rate variation across characters. Markov chain Monte Carlo analysis consists of four chains, which were run simultaneously with 2000000 trees, sampling 1/100 trees, with a burn-in value of 5000. The remaining trees were used to build a 50\% majority rule consensus tree, and statistical support of each node was assessed by posterior probabilities.

\section{Systematic Paleontology}

Infraclass TELEOSTEI Müller, 1845

Cohort CLUPEOCEPHALA Patterson \& Rosen, 1977

Superorder CLUPEOMORPHA Greenwood et al., 1966

Order ELLIMMICHTHYIFORMES Grande, 1982

Diplomystus clade 
162

163

164

165

166

167

168

169

170

171

172

173

174

175

176

177

178

179

180

181

182

183

184

Genus GUICLUPEA gen. nov.

Diagnosis: A fairly large-sized, double-armored ellimmichthyiform fish, differing from other genera of the order in the following combination of characters: dorsal body margin without marked angle at the dorsal fin insertion; posttemporal large; predorsal scutes series complete, with scutes small, numerous (about 55), all about equal in size, and with ridges on dorsal surface; number of predorsal bones ten or more; no diastema between second and third hypural; proximal end of middle principal caudal fin rays enlarged.

Etymology : 'gui', spelling or pingyin of the Chinese character '桂', the abbreviation in Chinese of the Guangxi Zhuang Autonomous Region, a province of China from where the fossil materials were collected; 'clupea', from the Latin, to indicate clupeomorph affinities of the new taxon.

Type species : Guiclupea superstes gen. et sp. nov., the only known species.

Guiclupea superstes gen. et sp. nov.

(Figs. 2-7)

Diagnosis: See generic diagnosis. Pectoral fin rays 18 , pelvic fin rays $5 \sim 6$, dorsal fin rays 14 , anal fin rays 38, total number of vertebrae about 46, 23 caudal and two ural vertebrae.

Etymology: 'superstes', Latin 'survivore'. The species name means that the species survived in the Oligocene when all members of the order Ellimmchthyiformes had become extinct.

Holotype: NHMG 005532, a nearly complete skeleton, part and counterpart (Figs. 2A-B). Paratypes: NHMG 033659 (Fig. 3A), a relatively complete skeleton with the snout and the caudal fin rays missing; NHMG 033658, a skeleton from the anterior margin of the orbital to the caudal peduncle, part of the anterior portion (Fig. 6) and counterpart of the posterior portion; 
185 NHMG 011648 (Fig. 7A), caudal peduncle to caudal fin, part and counterpart.

186 Additional material: NHMG 033660 (Fig. 5), disarticulated bones of the skull and anterior

187

part of the body; NHMG 004929, an incomplete skeleton with the posterior part of the body missing; NHMG 033661, disarticulated bones of the skull, the anterior ceratohyal and entopterygoid in this specimen are shown in Fig. 4F; NHMG 033680, disarticulated bones of the skull and anterior part of the body, the posterior ceratohyals in this specimen are shown in Fig. 4G; NHMG 033685, premaxilla (Fig. 4C); NHMG 038778, an incomplete skeleton with the head and caudal skeleton and fin missing; NHMG 033681-033683 and NHMG 038777, dentary (NHMG 033682 and 033683 shown in Figs. 4D and 4E respectively); NHMG 011647 and NHMG 011649, caudal skeleton and caudal fin; NHMG 011650-011651, caudal skeleton.

Localities and horizon: Gaoling Village $\left(22^{\circ} 07 \mathrm{~N}, 107^{\circ} 02^{\prime} \mathrm{E}\right)$, Ningming County, and Santang $\left(22^{\circ} 52^{\prime} \mathrm{N}, 108^{\circ} 25^{\prime} \mathrm{E}\right)$, Nanning, Guangxi province, China; middle to upper portion of the second member of the Yongning Group or Ningming Formation and Yongning Formation; Oligocene.

\section{Description}

(1) General Appearance. This new form is a fairly large-sized double-armored clupeomorph. The total length of the holotype (Figs. 2A-B) is about $526 \mathrm{~mm}$. In the known largest incomplete specimen, NHMG 033659 (Fig. 3A), the preserved portion reaches $638 \mathrm{~mm}$ in length, and the distance from the anterior margin of the lacrimal to the caudal fin base is about $585 \mathrm{~mm}$. The fish has an elongate fusiform body. The standard length in the holotype is about 3.3 times themaximum body depth. The anterior dorsal margin of the body is rounded and convex, without a marked angle at the origin of the dorsal fin as is typical in paraclupeids. The ventral border in front of the insertion of the pelvic fin is also convex, but is straight and rising obliquely upwards 
208 behind the insertion, making the posterior part of the body gradually narrower caudally. The

209 origin of the dorsal fin is posterior to the level of the insertion of the pelvic. The anal fin has a

210 long base. The caudal fin is deeply forked. There is a complete series of predorsal and ventral

211 scutes along the dorsal and ventral margins of the body. The meristic characters are listed in

212 Table 1.

213 (2) Skull Roof. The head is slightly longer than deep (Figs. 2A; 4A). The skull roof above the 214 orbit is narrow. The frontal is a long bone, with its posterior one-fourth expanding laterally; a

215 longitudinal ridge for the supraorbital sensory canal runs along its dorsal surface (Figs. 4A-B; 5).

216 The frontal sutures with the anterior edge of the parietal posteriorly. Two parietal bones meet at

217 the midline, at least in the anterior part (Fig. 4A-B), as in primitive clupeomorphs (Grande,

218 1985). No fontanelle between the anterior part of the frontals is observed, which is often present

219 in clupeoids and Paraclupea chetungensis (Chang and Grande, 1997). Anterior to the frontal is

220 the mesethmoid, which bears a lateral process on each side (Fig. 5). The lateral ethmoid,

221 contacting the frontal at its anteriolateral margin, is situated anterior to the orbit, forming the

222 lateral portion of the anterior wall of the orbit (Figs. 4A-B). The outlines of the pterotic and

223 sphenotic are not clear, but the strong ventrally directed process of the autosphenotic can be seen,

224 lying in front of the head of the hyomandibula (Fig. 4A-B). The supraoccipital is situated

225 posteriorly and sutures with the parietals anteriorly. The supraoccipital crest is well-developed,

226 high and triangular, making the lateral profile of the skull roof a distinct angle between the

227 anterior and the posterior parts (Fig. 4A-B). The external surface of all the skull roof bones lacks

228 ornamentation, except for a longitudinal ridge containing the supraorbital sensory canal (Figs.

$2292 \mathrm{~A}-\mathrm{B}, 4 \mathrm{~A}, 5,6 \mathrm{~A})$. No openings of the recessus lateralis are observed.

230 (3) Opercular Series and Cheek Bones. The opercle is trapezoidal in shape. Its ventral part is 
231 wider than the dorsal part, with the anteroventral corner protrudes downward and a little bit

232 forward. The depth of the opercle is about 1.5 times of its width. No ornamentation on the

233 surface of the opercle can be observed (Figs. 4A, 6). Two arms of the preopercle, with the dorsal

234 branch slightly longer than the ventral branch, form an obtuse angle. The preopercular sensory

235 canal runs along the mid-line of the bone sending out several branches backwards and

236 downwards. Interopercle and subopercle are long and thin, with smooth surface (Figs. 4A-B, 6A).

237 About 8-9 branchiostegal rays can be detected in the holotype, although the outline of each ray is

238 not very clear (Fig. 2A). In NHMG 033659, five of the posterior branchiostegal rays of the right

239 side can be counted below the interopercular bone, while four displaced, slender anterior

240 branchiostegal rays are discernible in the position anterior to the interopercle (Fig. 4A-B).

241 (4) Circumorbital Bones. There is an arched, long bone above the frontal in NHMG 033659

242 (Fig. 4A-B), we suspect it ought to be the supraorbital bone displaced from its original position.

243 The sclerotic ring, consisting of two halves, can be observed in the posterior and anterior part of

244 the orbit. Anterior to the orbit, two bones seem to bear sensory canals. The large, sub-triangular,

245 anterior thin bone is the lacrimal, whereas the posterior rectangular one may be infraorbital 2

246 (Fig. 4A-B). Detached infraorbital bones are preserved in NHMG 033660 (Fig. 5).

247

(5) Jaws and Palate. The mouth is somewhat superterminal on NHMG 004929. The oblique gape is relatively short, with the lower jaw articulation under the anterior border of the orbit (Fig.

4A; NHMG 004929). The upper jaw consists of a premaxilla, maxilla, and two supramaxillae.

The premaxilla is a small, long, and triangular bone, with a row of small conical teeth on its oral margin (Fig. 4C). The maxilla is a long bone, with its anterior part narrow and thick while its posterior part broadens into a thin blade and bears a rounded ventral profile. The oral margin of the thin blade is finely serrated. The anterior end of the maxilla develops into a round ethmoid 
254 head and a round palatine head (Fig. 5, NHMG 004929, 033684, 033686, 033689). Along the

255 dorsal edge of the maxilla, two supramaxillae can be detected in NHMG 004929 and 033659

256 (Fig. 4A). In NHMG 033689, two disarticulated supramaxillae bones seem to be roughly equal

257 in size and similar in shape; and their external surfaces are smooth, except for a low ridge

258 extending along their midline.

259 The mandible has a well-developed coronoid process formed by the dentary and the

260

261

262

263

264

265

266

267

268

269

270

271

272

273

274

275

276 anguloarticular. In NHMG 033681-3 and NHMG 038777, there is a single row of small conical teeth along the short oral margin of the dentary (Fig. 4D-E). Teeth close to the symphysis of the two dentaries are slightly stouter than those in the rear; but in specimen NHMG 033660, no teeth can be seen on the oral margin of the dentary. These may have been lost during preparation or fossilization. Along the lower lateral margin of the dentary, the mandibular sensory canal is well developed with 6 7 pores (Fig. 5). The anguloarticular is a triangular bone with the mandibular sensory canal running along its lower margin of the lateral surface. The length of anguloarticular is about half that of the dentary. Its posterior end forms the articular facet for the quadrate (Figs. 4A-B, 5). The very small retroarticular bone is located below the postarticular facet of the angulo-articular bone (Fig. 4A-B).

The quadrate, as is generally for teleosts, consists of a fan-like plate at its dorsal side and a rod-like posterior process at its ventral side. Its articular head fits into the socket at the posterodorsal end of the angulo-articular (Fig. 4A-B). The parasphenoid can be partly observed in NHMG 033658 and 004929 . It is difficult to judge whether or not a basipterygoid process and the "osteoglossid" tooth patch of the bone in most basal teleosts is present because of the preservation.

(6) Hyoid Arch and Gill Arches. The hyomandibular is a hatchet-like bone. It bears a thin, 
277 broad antero-dorsal plate and a long, narrow ventral shaft, which ventrally connects to the upper

278 end of the symplectic (Figs. 4A-B, 5). The condyle for articulation with the opercle is large.

279 From that level, a prominent ridge runs ventrally along the posterior margin of the outer surface

280 of the shaft. The foramen for hyomandibular branch of facial nerve (VII.hm) is clear. The

281 symplectic inserts into the notch between the plate of the quadrate and its ventral process (Figs.

282 4A-B). The detached entopterygoid is visible in NHMG 033660 and 033661 . It is a broad,

283 triangular bone, with numerous fine conical teeth covering its buccal side (Figs. 4F, 5). The

284 metapterygoid is an expansive, trapezoid bone. Its anterior margin is posterior to the anterior

285 margin of the quadrate, and its posterior margin reaches a relatively more dorsal position, almost

286 in line with the hyomandibular condyle (Figs. 4A-B, 6A).

287 The anterior ceratohyal is a thick, sub-rectangular plate with its length about twice of its depth.

288 Its dorsal margin is slightly convex, whereas its ventral margin is slightly concave. Its central

289 part is pierced by a large elongated oval foramen (Figs. 4F, 5) as in primitive clupeomorphs

290 (Grande, 1985). The posterior ceratohyal is a triangle plate without a foramen within it. There is

291 a small notch on its posterordorsal margin (Fig. 4G). The urohyal shows a narrow ventral keel

292 and a vertical crest. The height of the crest gradually increases posteriorly (Fig. 5). Gill arches

293 are not well-preserved, but many dislocated, long, pointed gill rakers with a bifid base that

294 embraced the gill arches are observed in several specimens (Figs. 3A, 4F-G, 5). The length of the

295 gill rakers varies from about one vertebral centrum to $2 \sim 3$ times as long as a vertebral centrum or

296 even more. There are numerous fine conical denticles recurved posteriorly throughout almost the

297 whole upper edge of the gill rakers, differing from the situation in Diplomystus sp. from the

298 English chalk, in which the rakers appear to be smooth throughout most of their length (Forey, $299 \quad 2004)$ 
300

301

302

303

304

305

306

307

308

309

310

311

312

313

314

315

316

317

318

319

320

321

322

(7) Paired Fins and Girdles. The posttemporal is a large bone (Figs. 4A-B; NHMG 004929).

The supracleithrum is small, lying below and posterior to the very well-developed posttemporal.

The cleithrum is a long, S-shaped bone, with its upper end covered by the supracleithrum. Below the cleithrum is the well-developed, laminate coracoid with a large notch on its anterior margin (Figs. 4A, 5-6). The pectoral fin is located rather high on the flank. The fin is long, extending past the insertion of the pelvic fin in NHMG 033658 (Fig. 6A). In other specimens, the fin rays do not look as long, probably because the distal ends of the fin rays were missing during the process of fossilization. Eighteen pectoral fin rays can be counted (Fig. 6A).

The pelvic girdle cannot be observed because of the covering of the abdominal scutes. The pelvic fin is small, with about 5 6 fin rays, inserted at the level in front of the origin of the dorsal fin (Figs. 2A, 6A). The length of the longest pelvic fin ray is equivalent to the span of $6 \sim 7$ postpelvic scutes.

(8) Dorsal and Anal Fins. The origin of the dorsal fin is situated slightly posterior to the midpoint of the standard body length. There are about 14 dorsal fin rays (Figs. 2A, 6A). The first two are short and unbranched, while the third through fifth rays are the longest. Twelve pterygiophores are preserved in the holotype. The first is comparatively long and broad, inserted between the tenth and eleventh neural spines, whereas those posterior to it are much narrower (Fig. 2A).

The origin of the anal fin is more posterior than the end of the dorsal fin base, closer to the pelvic fin insertion than to the caudal fin base. The anal fin base is comparatively long, containing about 38 rays, of which the anterior six are longer than the posterior ones. At least 36 pterygiophores are preserved in the holotype. In the specimen NHMG 038778, 38 pterygiophores can be counted. Anterior pterygiophores are longer than the posterior ones. The first 
323 pterygiophore inserts between the last rib and the first hemal spine (Figs. 2A, 3A).

324 (9) Vertebral Column. Twenty-three caudal vertebrae, excluding two ural centra, and

325

326

327

328

329

330

331

332

333

334

335

336

337

nineteen abdominal vertebrae are recognized in the holotype (Fig. 2A-B). We added two to our counts for the vertebrae that normally lie under the superficial bones of the skull and pectoral girdle (e.g., opercle, cleithrum); thus, the total number of the preural vertebrae is about 44 in the holotype. The length and depth of the vertebra are about equal, except the last few, which are shorter than the anterior ones (Figs. 2A, 3A). There are two longitudinal ridges along the lateral side of each vertebra, forming two pits on their lateral side (Fig. 3A). Halves of the neural arches are fused medially. The hemal spines start from the $21^{\text {st }}$ or $22^{\text {nd }}$ centrum, and their length decreases gradually until the fourth or fifth preural centrum where they increase greatly to support the fin rays of the lower caudal lobe (Fig. 7).

Nineteen pairs of ribs are present in the holotype, but in NHMG 033659 only 18 pairs of ribs could be counted. All the ribs insert deeply into the centra. Ventrally, these ribs touch the lateral wings of the abdominal scutes. There are numerous thin, long epineural and epipleural intermuscular bones. The epineural series extends from the occiput to the first preural centrum. The epipleural series starts from approximately under the last three abdominal vertebrae and extends to about the first preural centrum. The longest epineural reaches the length about five to six centra, and the longest epipleural is about the length of four to five centra (Figs. 2A-B, 3A, 6).

(10) Caudal Skeleton and Fin. The caudal skeleton and fin are preserved relatively well in specimens NHMG 011646-011651. The neural and haemal spines of the second to the fourth or fifth preural centrum are elongated and somewhat flattened in that of the second and third preural centrum, and support a few caudal fin rays and procurrent rays. The structure of the caudal skeleton, as a whole, differs from that in clupeiforms but closely resembles that in 
346 ellimmichthyiforms, i.e., bearing at least two autogenous uroneurals, the first one not fusing with

347 the first preural centrum as in Clupeoidei, although it is long and thick, extending anteriorly to

348 reach the anterodorsolateral side of that centrum. The second uroneural is much shorter than the

349 first one, extending anteriorly only to the anterior end of the second ural centrum, although its

350 distal end reaches that of the first one. It cannot be confirmed if a third uroneural is present or not.

351 There are two free ural centra; the first one is about equal in size to the first preural centrun, but

352 the second one is much shorter than the first one. Six hypurals are present. The proximal end of

353 first hypural is in contact with, but not fused to, the first ural centrum, although the narrow

354 second hypural is fused to the second ural centrum at its proximal end. Hypural 3 is the largest.

355 Anteriorly, its enlarged proximal end contacts with the distal end of the second ural centrum

356 entirely constraining the hypurals 4-6 reach anteriorly to contact the second ural centrum;

357 posteriorly, it expands, filling the entire space between the second and the fourth hypurals, such

358 that there is no diastema between them, as in Armigatus brevissimus and the Eocene Diplomystus

359 species. The fourth through sixth hypurals become narrower and shorter. The proximal end of the

360 parhypural is fused with the first preural centrum, which has a long, broad neural arch and spine.

361 There are three epurals (NHMG 011650). The caudal fin is deeply forked with the upper and

362 lower lobes of about equal length, containing 19 principal fin rays (I, 9-8, I), and eleven and nine

363 procurrent rays above and below the principal caudal fin rays, respectively (Figs. 2A, 7). The

364 proximal ends of the middle principal fin rays are preserved as impressions in NHMG 011648 ,

365 but the outline of the lowermost ray end of the upper lobe can be detected, it is significantly

366 enlarge. On NHMG 011649, the ends of two lowermost rays of the upper lobe and two uppermost rays of

367 lower lobe enlarge obviously, but only the end of the lowermost ray of upper lobe enlarges significantly as

368 in NHMG 011648. Three caudal scutes can be seen in the dorsal margin of the caudal fin in 
369

370

371

372

373

374

375

376

377

378

379

380

381

382

383

384

385

386

387

388

389

390

391

NHMG 011647.

(11) Predorsal Bones and Scutes. There are ten or eleven predorsal bones with thin anterior and posterior bony expansions. The anterior bones are broader than the posterior ones, and the first three stretch almost vertically (Figs. 2A-B, 3A) or somewhat postero-ventrally (Fig. 6), whereas the rest are oriented antero-ventrally.

There is a series of scutes along the dorsal margin from the occiput to the origin of the dorsal fin in the holotype. The entire series includes about 55 small, equally-sized scutes (Fig. 2).

Because of preservation, the details of the scutes cannot be observed in this specimen. In specimen NHMG 038778, about six predorsal scutes from immediately behind the occiput and about nine immediately anterior to origin of the dorsal fin can be recognized. The detail of the scutes cannot be observed also because of poor preservation. However, details can be discerned in NHMG 033658 (Fig. 6), in which numerous small dorsal scutes are preserved along the dorsal margin of the body from the occiput to the seventh predorsal bone. Most of the scutes are displaced, some of them are even turned upside-down and thus show their smooth ventral surface, but many scutes show their dorsal surface ornamented with several radial ridges. In NHMG 033659, a few predorsal scutes with weak ridges are preserved anterior to the dorsal fin. In NHMG 033680, several displaced dorsal scutes can be detected bearing radial ridges similar to those of NHMG 033658. No dorsal scutes are seen behind the dorsal fin base in any specimen. About 24 prepelvic scutes are counted from the posterior edge of the coracoid to the insertion of the pelvic fin in the holotype (Fig. 2A-B) and in NHMG 033658 (Fig. 6). Fourteen postpelvic scutes are present in the holotype. Only the first 11 postpelvic scutes are preserved in NHMG 033658. Several much smaller ventral scutes can be detected below the coracoids in the holotype or displaced in the lower part of the head in NHMG 033659. The scutes behind the coracoid bear 
392 a strong ventral spine and much higher lateral wings. The lateral wings are wider at their ventral

393 edges, but narrow gradually dorsally, extending from the ventral edge of the body up to about

394 one quarter of the way to the vertebral column (Figs. 2A, 3A, 6).

395 (12) Squamation/Scales. In NHMG 038778, the impression of some of the scales can be seen

396

397

398

399

400

401

402

403

404

405

406

407

408

409

410

411

412

413

414

in the body above the vertebral column. The scales are small. Details are not clear.

\section{DISCUSSIONS}

\section{Phylogenetic Relationships of the New Form}

Although the predorsal scutes of the new form do not expand laterally as in the diagnosis given by Grande (1982) of the Ellimmichthyiformes when he established the order, the presence of the two parietals meeting at the midline, a beryciform foramen within the anterior ceratohyal, ornamentation on the predorsal scutes, and the structure of the caudal skeleton suggest that the new species differs from clupeiforms but, instead, resembles ellimmichthyiforms (Grande, 1982, 1985). To further assess the systematic position of the new form, phylogenetic analyses were conducted.

Two data matrices were constructed for the phylogenetic analyses. Data matrix 1 (D1) used Chanos chanos as an outgroup taxon, whereas data matrix 2 (D2) used Elops saurus instead of Chanos chanos as the outgroup taxon. Each data matrix includes 55 morphological characters and 40 taxa (see Apeendix 2S-3S), analyzed using parsimony and Bayesian inference methods respectively.

The analysis of D1, using parsimony criteria, generated four equally most parsimonious trees (MPTs). A strict consensus tree (SCT1) of 189 steps was built, with a consistency index (CI) of 0.323 and retention index (RI) of 0.670 (Fig. 8, Appendix Figure 1S). The SCT1 shows two main clades of Clupeomorpha: Clupeiformes and Ellimmichthyiformes. The monophyly of the 
415 Ellimmichthyiformes, including Ornategulum as the most basal taxon, is supported by the

416 following features: two parietals meeting at the midline (2:0), two supramaxillary bones $(8: 0)$,

417 presence of the "basipterygoid" process (9:1), anterior ceratohyal with foramen (11:1), and three

418 epurals (38:0). Three of these four characters (i.e., 2, 9, and 11) are uniquely derived characters

419 (ci=1) for this clade. Gasteroclupea and Sorbinichthys lie in the basal position of the

420 Ellimmichthyiformes, but do not form sister groups as suggested by Marramà et al. (2019) and

421 Boukhalfa et al. (2019). Sorbinichthyidae sensu Murray and Wilson 2013 including only the two

422 Sorbinichthys species, is strongly supported by a number of derived characters: broad dorsal

423 process of the posttemporal (15:2), posterior predorsal scutes laterally expanded (41:1), the most

424 posterior predorsal scutes enlarged (44:1), high number of abdominal scutes (51:2), but fewer

425 postpelvic scutes (52:1). Monophyly of Armigatus is supported by sharp proximal end of first

426 hypural (27:1), predorsal scute series incomplete (39:0) (ci=1). Monophyly of Diplomystus

427 (excluding D. solignaci Gaudant 1971) is supported by the presence of sub-rectangular scutes in

428 anterior and posterior predorsal series (40:1 and 41:1), and presence of a series of spines on

429 posterior margin of lateral wings of predorsal scutes $(42: 1)(\mathrm{ci}=1)$. Diplomystus solignaci is a

430 member of the paraclupeid clade as suggested in many previous studies (Alvarado-Ortega et al.,

431 2008; Murray \& Wilson 2013; Figuereido \& Ribeiro 2016; Marramà et al., 2019; Boukhalfa et

432 al., 2019). Armigatus is in a more basal position of Diplomystus as suggested by Alvarado-

433 Ortega et al. (2008) and Figuereido \& Ribeiro (2016). Our new form, Guiclupea, forms the sister

434 group to Diplomystus sensu stricto. The membership of Paraclupeidae, not including

435 Kwangoclupea and Codoichthys as some previous studies suggested (e.g., Murrey and Wilson,

436 2013; Francisco and Figueiredo, 2016; Marrama et al., 2018; Boukhalfa et al., 2019) but in some

437 ways consistent with the recent analysis conducted by Vernygora and Murray (2020), is 
438 supported by the dorsal outline forming a marked angle at dorsal-fin insertion (1:1), first

439 uroneural extending forward to second preural centrum (32:0), and predorsal scutes with ridges

440 on the dorsal surface $(44: 1)$.

441 The analysis of D1 using a Bayesian inference method, generated a Bayesian Inference tree 442 (BIT) (Fig. 9). As in SCT1, the monophyly of Sorbinichthys, Armigatus, Diplomystus sensu 443 stricto, and Paraclupeidae is supported, and Guiclupea is sister to Diplomystus sensu stricto. 444 Unfortunately, the monophyly of the Clupeiformes cannot be supported, and Gasteroclupea, 445 Sorbinichthys, and Kwangoclupea lie in a more derived position than that of SCT1.

446 The analysis of D2, using parsimony criteria, recovered 16 MPTs. The SCT of the 16 MPTs 447 (see Appendix Figure 3S) is 188 in step, the CI is 0.324 , and the RI is 0.671 . The cladogram of 448 SCT2 shows that Ornategulum is in the basalmost position of the superorder, i.e., Ornategulum does not belong to the Ellimmichthyiformes as suggested by SCT1 and BIT1. The monophyly of the Clupeiformes, Sorbinichthys, and the remaining members of the Ellimmichthyiformes clade exclusive of Gasteroclupea was all supported, and the last one has the same topology as in SCT1. The topology of BIT2, resulting from the analysis of D2, is very similar to that of BIT1 except

SCTs and in the two BITs respectively, but differ between the SCTs and the BITs. In the BITs, Armigatus lies in the basalmost position of the order but it is not so in the SCTs. In the BITs, 
461 Gasteroclupea belongs to the Sorbinichthyidae as suggested by Marramà et al. (2019) and 462 Boukhalfa et al. (2019); but in the SCTs, Gasteroclupea does not form the sister group to

Sorbinichthys. Kwangoclupea forms the sister group to Codoichthys and lies in a relatively basal position in the two SCTs, whereas it lies in a relatively derived position and belongs to the Paraclupeidae in the two BITs. These differences between the general topologies of the SCTs and BITs are probably due to the fact that the information contained in the dataset is insufficient to draw firm conclusions about their relationships as pointed out in the recent analyses of the phylogeny of Ceratomorpha (Bai et al., 2020). To improve the understanding of relationships of the group, more phylogenetically informative fossils and more complete data are needed.

Although there are discrepancies between the MPTs and BITs, and between the trees with alternative outgroups, the general topologies of the four trees mentioned above are basically similar, and all the four trees suggest that the new form is a member of the ellimmichthyiforms and forms a sister group to Diplomystus sensu stricto. The close relationship of these two is supported by high supraoccipital crest (4:1), pelvic-fin insertion in advance of dorsal fin origin (22:0), and number of predorsal scutes $\geq 20$ (46:1). Actually, in addition to these synapomorphies, the new form and Diplomystus sensu stricto, especially the Eocene species, i.e., D.dentatus and D. shengliensis, share many more similar characters, such as having an elongated fusiform body form, dorsal outline curved gently, no ornamentation on the skull bones, entopterygoid with teeth, high number of anal fin rays (23-25 in D. birdi, 27 in D. dubertreti, 38-41 in D. dentatus, about 39 in D. shengliensis, and about 38 in Guiclupea superstes), close-to fan shape arrangement of the predorsal bones, and no diastema between the second and third hypural (but there is a gap between second and third hypural in the Late Cretaceous species, i.e., D. birdi and D. dubertreti (Chang \& Maisey 2003, p27)). The last character also occurs in pristigasteroids, and 
484

485

486

487

488

489

490

491

492

493

494

495

496

497

498

499

500

501

502

503

504

505

506

osteoglossids, some elopomorphs, and a number of ostariophysans (Chang \& Maisey, 2003). The differentiation between Diplomystus and Guiclupea is in the shape and ornamentation of the predorsal scutes (sub-rectangular vs. ovate, presence vs. absence of pectinate posterior border, dorsal surface smooth vs. with radial ridges), and the number of predorsal bones (6-8 vs. 10-11). Accordingly, the new form is a distinct genus and species, and can be easily distinguished from Diplomystus. Comb-like teeth along the posterior edges of the dorsal scutes is a derived character of Diplomystus. In addition to Diplomystus, sub-rectangular predorsal scutes also occur in most members of the Paraclupeidae. As far as the radial ridges on the dorsal surface of predorsal scutes is concerned, they usually occur in paraclupeids, such as Paraclupea, Ellimmichthys, Ellimma, Triplomystus, etc., and these forms usually have a marked angle at the insertion of the dorsal fin, and sub-rectangular dorsal scutes at least in the posterior part of the scute series. The new form is distinct from them in the shape of the body and predorsal scutes. Among the species with ornamentation on the predorsal scutes, the new form resembles Scutatuspinosus itapagipensis in the shape of the body and predorsal scutes (not laterally expanded), and posterior expansion of the third hypural, leaving no gap or notch between the second and third hypurals. However, there are obvious differences between the two forms in the number of predorsal scutes and anal fin rays, ornamentation on the skull roof bones, and the size and shape of the abdominal scutes. Previous studies (Yabumoto, 1995; Chang and Grande, 1997) suggest that "Diplomystus" from Japan (Uyeno, 1979; Yabumoto et al 2006) are closely related to Paraclupea chetungensis in having ridges on the dorsal scutes, however, the shape of the body (not deep, no marked angle at the origin of the dorsal fin) and dorsal scutes (not laterally expanded, all scutes about the same size) of the Japan material are obviously different from that of Paraclupea but resemble that of the new form, but the new form differs from the 
507

508

509

510

511

512

513

514

515

516

517

518

519

520

521

522

523

524

525

526

527

528

529

"Diplomystus" from Japan at least in the neural spines of the vertebrae not seperated and the number of anal fin rays, vertebrae, predorsal and ventral scutes, and predorsal bones. To assess the systematic position of the "Diplomystus" from Japan, reexamination of the material is needed. On the whole, the new form displays a mosaic combination of characters. It bears radial ridges on the dorsal surface of the predorsal scutes as in the paraclupeids, but the scutes are all about the same size as in Armigatus and Diplomystus. Consequently, Guiclupea can easily be distinguished from all known ellimmichthyiforms in number and morphology of the dorsal scutes and allow us to recognize that predorsal scutes with ridges on the dorsal surface are not unique to Paraclupeidae.

\section{Body shape and size of the Ellimmichthyiformes}

The ellimmichthyiforms are diverse in both general morphology and body size. Generally, ellimmichthyiforms show two types of body form. One bears a deep body, with the maximum depth/standard length (MD/SL) larger than 50\%, and some of them even with the MD roughly equal to, or slightly larger than the SL in adult specimens, e.g., in Tycheroichthys dunveganensis and Rhombichthys intoccabilis (Hay et al., 2007; Khalloufi et al., 2010). Most of them are referred to the paraclupeids. The other kind of fishes have an elongate fusiform shape, the $\mathrm{MD} / \mathrm{ST}$ often less than $50 \%$. They occupy a relatively basal position in the Ellimmichthyiformes, such as Armigatus, Diplomystus, and Guiclupea.

Body size of ellimmichthyiforms ranges from several centimeters to about $65 \mathrm{~cm}$ in TL. The known smallest fish is Eoellimmichthys superstes with the TL and SL about $17.5 \mathrm{~mm}$ and 13.7 mm, respectively (Marramà et al., 2019). Many species have a TL less than 100 mm, such as Armigatus alticorpus, A. dalmaticus, A. oligodentatus, Codoichthys carnavalii, Diplomystus shengliensis, "Diplomystus" trebicianensis, Ellimmichthys maceioensis, Eoellimmichthys 
530

531

532

533

534

535

536

537

538

539

540

541

542

543

544

superstes, Gasteroclupea branisai, Scutatuspinosus itapagipensis, Sorbinichthys africanus,

Thorectichthys marocensis, T. rhadinus, and Tunisiaclupea speratus. Species with TL larger than $200 \mathrm{~mm}$ are rare. The TL of Rhombichthys intoccabilis reaches about $230 \mathrm{~mm}$ in the holotype (Khalloufi et al., 2010, fig. 3). The predorsal length of Horseshoeichthys armigserratus, from the Maastrichtian of Canada, is $172 \mathrm{~mm}$, with the estimated SL about 260-280 mm (Newbrey et al., 2010). Specimens with SL over $300 \mathrm{~mm}$ are only seen in Diplomystus dentatus from the Eocene of the United States, on the eastern side of the Pacific and Guiclupea superstes from the Oligocene of South China, on the western side of the Pacific so far. The former reaches a TL of about $650 \mathrm{~mm}$ (Grande, 1982) while the latter reaches a SL about $600 \mathrm{~mm}$. They are the largest ellimmichthyiform fishes known. It is noted that the phylogeny of the Diplomystus clade show a trend toward increase their body size, as the trend has been observed in many clades of rayfinned fish (Guinot and Cavin, 2018) over a long time interval. In the Cretaceous, members of this order usually have a small body length; it is not until the end of the Cretaceous that some members (e.g., Horseshoeichthys armigserratus) attained a relatively large body-size; in the late Paleogene, some members developed an even larger body size. It is worth mentioning that the fishes with large body size all are members of the Diplomystus clade (Horseshoeichthys forms the sister group to Diplomystus species (Veryngora \& Murray, 2020)) and occur on the sides of the Pacific. Both Horseshoeichthys armigserratus from the end-Cretaceous and Guiclupea superstes from the Oligocene occurred at a time of global cooling, the former even lived at about $60^{\circ} \mathrm{N}$ paleolatitude (Newbrey et al. 2010), the latter lived in the environment where the temperature lower than the $22^{\circ} \mathrm{C}$ of the Ningming area today (Shi et al., 2012). However, the Diplomystus dentatus occurred in early-middle Eocene, at a time of global greenhouse climate or the early Eocene Climatic Optimum (Zachos et al. 2001), and no large-size of the conterporary 
553

554

555

556

557

558

559

560

561

562

563

564

565

566

567

568

569

570

571

572

573

574

Diplomystus shenliensis and Eoellimmichthys have been reported. So, the relationship of the body size with the climate within this group is no clear.

Several studies indicated that enlarged body size of fishes are associated with their lifestyles. A recent study based on a comparative analysis indicates that across the Clupeiformes diadromous species are larger than non-diadromous species, for increased body size is an adaptation to the energetic long-distance migration. No association of body size with trophic position was found (Bloom et al., 2018). Another study based on over 4500 migratory and nonmigratory species of ray-finned fishes, also shows that migratory species are larger than nonmigratory relatives in nearly all clades and across all modes of migration (Burns \& Bloom, 2020). Based on extant and fossil data covering the Late Jurassic-Paleocene interval, Guinot and Cavin (2018) suggested that the proportion of body size shifts associated with environmental transitions more than within a given environment, especially for major positive body size shifts towards mixed environments. From these studies, we have reason to speculate that the wide-spread Diplomystus clade possibly involve some amphidromous or migratory species.

\section{Paleobiogeographic history of the Ellimmichthyiformes}

The Ellimmichthyiformes, like its sister-group the Clupeiformes (Lavoué et al., 2013, 2014), is a cosmopolitan group of fishes, with members distributed worldwide in marine, euryhaline and freshwater, and exhibit a complex paleobiogeographic history (Fig. 1). The oldest known ellimmichthyiform fish so far is Ezkutuberezi carmenae from the Valanginian-Barremian of northern Spain (Poyato-Ariza et al., 2000). Fossils from Hauterivian-Barremian include Scutatuspinosus itapagipensis and Ellimmichthys longicostatus from northeastern Brazil (Figueiredo \& Ribeiro 2017; Cope, 1886), Tunisiaclupea speratus from southern Tunisia 
575 (Boukhalfa et al., 2019), and Paraclupea chedungensis from eastern China (Sun, 1956; Chang \&

576 Grande, 1997; Hu et al., 2017). All these species belong to the Paraclupeidae and distributed in

577 non-marine sediments. The paraclupeid fishes are abundant during the late Early Cretaceous

578 (Aptian-Albian). There are Ellimma branneri and Ellimmichthys maceioensis from Alagoas

579 (Schaeffer, 1947; Chang and Maisey 2003; Malabarba et al., 2004), and Ellimma longipectoralis

580 from Santos Basin (Polck et al., 2019) of Brazil; Ellimmichthys goodi from Equatorial Guinea

581 (Eastman, 1912); and Paraclupea seilacheri from Puebla, Mexico (Alvarado-Ortega and

582 Melgarejo-Damián 2017). In addition to paraclupeids, there are Codoichthys carnavalii from the

583 Aptian of Brazil (de Figueiredo and Ribeiro, 2016), Foreyclupea loonensis from the Albian of

584 Canada (Vernygora et al., 2016, the authors thought this species should be closely related with

585 Scutatuspinosus itapagipensis), and the recently described Armigatus carrenoae from marine

586 Albian of Central Mexico (Alvarado-Ortega et al. 2020). These indicate that the

587 Ellimmichthyiforms had been diversified and distributed widely during the Early Cretaceous in

588 Europe, South and North America, Africa, and East Asia. The close relationship between the

589 Early Cretaceous fish faunas from northeastern South America and from western Africa might

590 have resulted from the contiguous margins of Brazil and West Africa during the Early

591 Cretaceous (Chang and Grande, 1997) or resulted from Tethys Sea and the South Atlantic Ocean

592 were intermittently connected through North-South Trans-Saharan seaways, as postulated by

593 Lavoué et al. (2013). But there is little geologic evidence to support an Early Cretaceous non-

594 marine paleogeographic connection between the eastern Asiatic margin and western Gondwana.

595 Consequently, the distribution pattern of paraclupeids in the Early Cretaceous is faced with a 
596

597

598

599

600

601

602

603

604

605

606

607

608

609

610

611

612

613

614

615

616

biogeographic conundrum. No favorable hypothesis adequately explains this distribution pattern

to date. Chang and Maisey (2003) suggested that either a substantial portion of their non-marine

fossil record is missing or their distribution involved marine dispersal.

During the early Late Cretaceous, the Ellimmichthyiformes reaches their greatest diversity.

Not only the Paraclupeidae and Armigatidae or Armigatus are highly diversified in the

Mediterranean region and the former extended their range to North America (Tycheroichthys

dunveganensis from Canada, Hay et al., 2007), but all other main ellimmichthyiform clades, i.e.,

Sorbinichthydae and Diplomystus clade, occurred and flourished in the Cenomanian with their

oldest record from the eastern Tethys (Lebanon) (Woodward, 1895; Signeux, 1951; Grande,

1982; Zhang et al., 1985; Bannikov \& Bacchia, 2000; Murray \& Wilson, 2011; 2013; Murray et

al., 2016). With all main clades first occurring there, undoubtedly, the circum-Mediterranean

region is a hotspot on the evolution of ellimmichthyiforms. Species of Diplomystus are also

found from the Cenomanian English chalk (Forey, 2004). The diversity of ellimmichthyiforms

during the early Late Cretaceous was probably resulted from the high sea surface temperatures,

eustasy and the consequent land-sea distribution that increased food input, dispersal routes, and

habitat fragmentation for these fishes (Guinot \& Cavin 2016; Boukhalfa et al., 2019). Toward the

end of the Cretaceous, the diversity of the Ellimmichthyiformes suddenly declined. Only

Gasteroclupea branisai from South America and Horseshoeichthys armigserratus from North

America are known to date.

Rare ellimmichthyiforms survived after the Cretaceous-Paleogene boundary. Gasteroclupea

branisai, Eoellimmichthys superstes, and Diplomystus clade are the exceptions. Gasteroclupea

Peer) reviewing PDF | (2020:12:56381:1:1:NEW 30 Mar 2021) 
617 branisai first occurred in the Late Cretaceous of South America and survived to the Danian of

618 Argentina and Bolivia (Signeux, 1964; Marramà \& Carnevale, 2017). Eoellimmichthys

619 superstes is a paraclupeid from the marine Eocene of Italy. Interestingly, Diplomystus clade not

620 only survived up to the Oligocene, but also had a relatively wide distribution range along both

621 sides of the Pacific Ocean (see Fig. 1). Horseshoeichthys armigserratus occurred in western

622 side of North America at the end of the Cretaceous (Newbrey et al., 2007). The Eocene

623 Diplomystus occurred on both sides of the Pacific Ocean (along the coast of the Bohai Gulf,

624 east China, and in western North America) with species bearing a striking similarity in

625 morphology (Zhang et al., 1985; Chang \& Maisey, 2003). Their sister group, Guiclupea

626 superstes, survived to the Oligocene as the youngest ellimmichthyiform fish. The Eocene

627 "transpacific" distribution pattern of Diplomystus and other fishes and terrestrial vertebrates has

628 long been noted by paleontologists (Chang \& Chow, 1978; Grande, 1982, 1985; Zhang et al.,

629 1985). A broad connection between Asia and North America in the Bering Strait area and

630 temporary desalination of the Arctic Ocean could have facilitated the dispersal of these fishes

631 (Chang \& Maisey, 2003). It is interesting to find that all ellimmichthyiform fossil localities (Fig.

632 1) are close to the recent coast except some of the North American localities. Many

633 contemporaneous fish faunas have been found from inland areas of China, Mongolia, and East

634 Kazakhstan (Tang, 1959; Liu et al., 1962; Wang et al., 1981; Sytchevskaya, 1986), but no

635 ellimmichthyiforms have ever been reported from there yet. Many Cretaceous fishes are found

636 from Zhejiang and Fujian Provinces, East China, but Paraclupea only occurred in the eastern

637 region of the provinces, although there are many contemporaneous fishes, such as

Peer] reviewing PDF | (2020:12:56381:1:1:NEW 30 Mar 2021) 
638

640

641

642

643

644

645

646

647

648

649

650

651

Paralycoptera and others, from the middle and western part of the provinces (Chang \& Chou, 1977). In addition, most Recent Clupeomorphs inhabit the sea, a few dwell not far away from coastal regions; many taxa within a lineage co-occur in fresh and marine waters and in temperate and tropical areas, and water temperature and salinity are seen as the usual case and poor dispersal barriers for this group of fishes (Lavoué et al. 2014). It seems reasonable to suggest that the origin and dispersal of ellimmichthyiforms may have something to do with the sea.

\section{CONCLUSION}

Guiclupea superstes from the Oligocene of south China represents the youngest record of ellimmichthyiform. Its occurrence indicates that the Ellimmichthyiformes had a wider distribution range and a longer evolutionary history than previously knew. Guiclupea superstes is closely related to Diplomystus sensu stricto, which suggests that the dorsal scutes with ridges on dorsal surface is not a character unique to paraclupeids.

Paraclupeids has a comparatively long evolutionary history. They were very diverse and widely distributed during the Early through early Late Cretaceous, and survived to the Eocene in the circum-Mediterranean area. Sorbinichthys and Armigatus were restricted to the Mediterranean region in the early Late Cretaceous, but Armigatus had been distributed in Mid America (Mexico) during Albian. Diplomystus clade might have originated not later than the Cenomanian, and disappeared from Europe and the Middle East after the early Late Cretaceous, but was still prospering in the Pacific sides from the end of the Cretaceous to Eocene and 
659

660

661

662

663

664

665

666

667

668

669

670

671

672

673

674

675

676

677

678

679

680

681

survived until the Oligocene. This allowed the Ellimmichthyiformes to obtain a particularly long distribution range on the western side of the Pacific.

There is still no consensus among ichthyologists on the phylogenetic relationships of the Ellimmichthyiformes, especially the relationship of Armigatus and Diplomystus, as well as the position of Gasteroclupea and Codoichthys. Besides, there are discordances between the most parsimonious tree and the Bayesian Inference tree. To solve these problems, more informative specimens and characters are needed to enhance the dataset.

\section{Acknowledgments}

We thank Zhanxiang Qiu from IVPP for his kind help in creating the species name, Alison M Murray from University of Alberta for providing references, Weicai Chen from Nanning Normal University for help in conducting MrBayes analyses, Desui Miao from University of Kansas for stylistic improvement. Thanks are extended to Lidi Cen, Xueqiang Lei, and Qiongyao Fu from NHMG for preparing the fossil specimens, Guodun Kuang, Qiuping Zhu, Zhiming Xie, and many other colleagues for their hard work in the field. Thank reviewers Alison M Murray and Lionel Cavin for making very valuable suggestions for the improvement of the manuscript.

\section{LITERATURE CITED}

Alvarado-Ortega J, Melgarejo-Damián MP. 2017. Paraclupea seilacheri sp. nov., a double armored herring (Clupeomorpha, Ellimmichthyiformes) from the Albian limestones of Tlayua quarry, Puebla, Mexico. Revista Mexicana de Ciencias Geologicas 34:234-249.

Alvarado-Ortega J, Ovalles-Damián E. 2008. Triplomystus applegatei, sp. nov. (Teleostei: Ellimmichthyiformes), a rare "triple armored herring” from El Espinal Quarry (Early Cretaceous), Chiapas, southeastern Mexico. Journal of Vertebrate Paleontology 28:53-60. 
682 Alvarado-Ortega J, Ovalles-Damián E, Arratia G. 2008. A review of the interrelationships of 683 the order Ellimmichthyiformes (Teleostei: Clupeomorpha). In Arratia G, Schultze H-P, 
Ellimmichthyiformes) from the Lower Cretaceous Sidi Aich Formation of southern Tunisia: phylogenetic and paleobiogeographic implications. Journal of Vertebrate Paleontology DOI $10.1080 / 02724634.2018 .1529675$

\section{Bureau of Geology and Mineral Resources of Guangxi Zhuang Autonomous Region. 1985.} Tertiary System. Regional Geology of Guangxi Zhuang Autonomous Region (in Chinese with English summary). Beijing: Geological Publishing House, 267-280.

Burns MD, Bloom DD. 2020. Migratory lineages rapidly evolve larger body sizes than nonmigratory relatives in ray-finned fishes. Procedings of the Royal Society B 287:20192615. http://dx.doi.org/10.1098/rspb.2019.2615

Chang MM, Chow CC. 1977. On late Mesozoic fossil fishes from Zhejiang Province, China. Memoirs, Institute of Vertebrate Paleontology and Paleoanthropology. Academia Sinica 12:1-60. (In Chinese with English summary)

Chang MM, Chow CC. 1978. On the fossil fishes in Mesozoic and Cenozoic oil-bearing strata from east China and their sedimentary environment. Vertebrata PalAsiatica 16(4):229-237.

Chang MM, Grande L. 1997. Redescription of $\uparrow$ Paraclupea chetungensis, an early Clupeomorph from the Lower Cretaceous of Southeastern China. Fieldiana Geology 37:119.

Chang MM, Maisey JG. 2003. Redescription of $\dagger$ Ellimma branneri and $\dagger$ Diplomystus shengliensis, and relationships of some basal clupeomorphs. American Museum Novitates 3404:1-35.

Chen GJ, Chang MM. 2011. A new early cyprinin from Oligocene of South China. Science China Earth Sciences 54(4):481- 492.

Chen GJ, Liu J, Chang MM. 2018. Evolutionary hotspot of Cenozoic fish: Paleogene 
728

729

730

731

732

733

734

735

736

737

738

739

740

741

742

743

744

745

746

747

748

749

750

ichthyofauna from the onshore basins around Beibu Gulf (in Chinese with English summary). Chinese Science Bulletin 63, DOI 10.1360/N972018-00569

Cope E D. 1886. A contribution to the vertebrate paleontology of Brazil. Proceedings of the American Philosophical Society 23:3-4.

Dong JL, Sun BN, Mao T, Liu CH, Wang XL, Sun MX, Ma FJ, Wang QJ. 2017. The occurrence of Burretiodendron from the Oligocene of South China and its geographic analysis. Palaeogeography. Palaeoclimatology. Palaeoecology http://dx.doi.org/10.1016/j.palaeo.2017.07.004

Eastman C R. 1912. Tertiary fish-remains from Spanish Guinea in West Africa. Annals Carnegie Museum 8:370-378.

Figueiredo FJ, Ribeiro DRM. 2016. Relationships of $\dagger$ Codoichthys carnavalii Santos, 1994 (Teleostei, Clupeomorpha, †Ellimmichthyiformes) from the late Aptian of São Luís-Grajaú basin, NE Brazil. Anais da Academia Brasileira de Ciências 88:1277-1307.

Figueiredo F J, Ribeiro DRM. 2017. Reassessment and Relationships of $\dagger$ Scutatuspinosus itapagipensis (Teleostei, Clupeomorpha, $\uparrow$ Ellimmichthyiformes) from the Neocomian of Reconcavo Basin, Northeastern Brazil. Anais da Academia Brasileira de Ciências 89:799823.

Forey P L. 2004. A three-dimensional skull of a primitive clupeomorph from the English Chalk and implications for the evolution of the clupeomorph acusticolateralis system. In Arratia G, Tintori A, eds. Mesozoic Fishes 3 - Systematics, Paleoenvironments and Biodiversity, München: Verlag Dr. Friedrich Pfeil, 405-427.

Forey PL, Yi L, Patterson C, Davies CE. 2003. Fossil Fishes from the Cenomanian (Upper Cretaceous) of Namoura, Lebanon. Journal of Systematic Palaeontology 1:227-330. 
751 Gaudant M, Gaudant J. 1971. Une nouvelle espèce de Diplomystus (Poisson téléostéen) dans

752 le Crétacé supérieur du Sud tunisien. Bulletin de la Society Géologique de France 13:156$753 \quad 159$.

754 Goloboff PA, Farris JS, Nixon KC. 2008. TNT, a free program for phylogenetic analysis. $755 \quad$ Cladistics 24:774-786.

756 Grande L. 1982. A revision the fossil genus Diplomystus, with comments on the 757 interrelationships of clupeomorph fishes. American Museum Novitates 2728:1-34.

758

759

760

761

762

763

764

765

766

Grande L. 1985. Recent and fossil Clupeomorph fishes with material for revision of the subgroups of Clupeoids. Bulletin of the American Museum of Natural History 181:231-372.

Greenwood PH, Rosen DE, Weitzman SH, Myers GS. 1966. Phyletic studies of teleostean fishes, with a provisional classification of living forms. Bulletin of the American Museum of Natural History 131:339-455.

Guinot G, Cavin L. 2016. 'Fish' (Actinopterygii and Elasmobranchii) diversification patterns through deep time. Biological Reviews 91(4): 950-981. DOI: 10.1111/brv.12203

Guinot G, Cavin L. 2018. Body size evolution and habitat colonization across 100 million years (Late Jurassic-Paleocene) of the actinopterygian evolutionary history. Fish and Fisheries 19(4):577-597.Hay MJ, Cumbaa SL, Murray AM, Plint A G. 2007. A new paraclupeid fish (Clupeomorpha, Ellimmichthyiformes) from a muddy marine prodelta environment: middle Cenomanian Dunvegan Formation, Alberta, Canada. Canadian Journal of Earth Sciences 44:775-790.

Hu G, Hu WX, Cao J, Yao SP. 2017. Stratigraphic correlations and occurrence patterns of two sets of Lower Cretaceous black shales in coastal southeastern China and geological implications: insights from zircon U-Pb ages. Geological Journal 52:5894-608. 
774

775

776

777

778

779

780

781

782

783

784

785

786

787

788

789

790

791

792

793

794

795

796

Khalloufi B, Zaragüeta-Bagils R, Lelièvre H. 2010. Rhombichthys intoccabilis, gen. et sp. nov. (Ellimmichthyiformes, Clupeomorpha, Teleostei), from the Cenomanian (Upper Cretaceous) of Ein Yabrud, Middle East: anatomical description and phylogenetic implications. Journal of Vertebrate Paleontology 30:57-67.

Lavoué S, Konstantinidis P, Chen W-J. 2014. Progress in clupeiform systematics. In Ganias K, ed. Biology and ecology of sardines and anchovies (Vols. 1-0, pp. 3-42). Boca Raton, FL: CRC Press. http://www.crcnetbase.com/doi/abs/10.1201/b16682-3

Li HM, Chen YF, Chen GJ, Kuang GD, Huang ZT. 2003. Tertiary fossil winged fruits of Palaeocarya from Ningming of Guangxi, S. China (in Chinese with English summary). Acta Palaeontologica Sinica 42:537-547.

Li R, Qiu DZ, Li GR. 1995. Tertiary sedimentary facies and their controls on the reservoir quality in the Ningming region, Guangxi. Petrofacies and Paleo-geography 5(3):40-45. (Chinese with English abstract)

Liu T S, Liu H T, Tang X. 1962. A new percoid fish from South China (in Chinese). Vertebrata PalAsiatica 6:121-129.

Ma FJ, Liu S, Sun BN, Yan DF, Dong JL, Zhang FT, Wang QJ. 2017. Legume fruits from the Oligocene Ningming Formation of Guangxi, China, and their biogeographical and palaeoclimatic implications. Review Palaeobotany Palynology 244:192-202.

Malabarba MC, Carmo DAD, Gómez-Pérez I, De Queiroz-Neto JV. 2004. A new clupeomorph fish from the Cretaceous Maceió Formation, Alagoas Basin, NE Brasil. Neues Jahrbuch fur Geologie und Paläontologie 233:255-274.

Marramà G, Carnevale G. 2017. The relationships of Gasteroclupea branisai Signeux, 1964, a freshwater double-armored herring (Clupeomorpha, Ellimmichthyiformes) from the Late 
Cretaceous-Paleocene of South America. Historical Biology 29:904-917.

798

Marramà G, Bannikov AF, Kriwet J, Carnevale G. 2019. An Eocene paraclupeid fish (Teleostei, Ellimmichthyiformes) from Bolca, Italy: the youngest marine record of doublearmoured herrings. Papers in Palaeontology 5(1):83-98.

Muller J. 1845. Über den Bau und die Grenzen der Ganoiden undüber das natürlichen System der Fische. Abhandlungen der Königlich Preussischen Akademie der Wissenschaften 1844:117-216.

Murray AM, Wilson MVH. 2011. A new species of Sorbinichthys (Teleostei: Clupeomorpha: Ellimmichthyiformes) from the Late Cretaceous of Moroccco. Canadian Journal of Earth Sciences 48:1-9.

Murray AM, Wilson MVH. 2013. Two new paraclupeid fishes (Clupeomorpha: Ellimmichthyiformes) from the Upper Cretaceous of Morocco. In Arratia G, Schultze HP, Wilson MVH, eds. Mesozoic Fishes 5 - Global Diversity and Evolution. Munich: Verlag Dr. Friedrich Pfeil, 267-290.

Murray AM, Vernygora O, Japundẑić S, Radovcic J, Wilson MVH, Bardarck D, Grande T. 2016. Relationships of the species of Armigatus (Clupeomorpha, Ellimmichthyiformes) and the description of a new species from the Cretaceous of Dalmatia, Croatia. Journal of Vertebrate Paleontology. DOI 10.1080/02724634.2017.1226851.

Nelson JS, Grande TC, Wilson MVH. 2016. Fishes of the World. 5th ed. New Jersey: John Wiley and Sons, Inc.

Newbrey MG, Murray AM, Brinkman DB, Wilson MVH, Neuman AD. 2010. A new articulated freshwater fish (Clupeomorpha, Ellimmichthyiformes) from the Late Cretaceous Horseshoe Canyon Formation, Alberta, Canada. Canadian Journal of Earth Sciences 47: 
1183-1196.

821 Patterson C, Rosen D E, 1977. Review of ichthyodectiform and other Mesozoic teleost fishes and the theory and practice of classifying fossils. Bulletin of the American Museum of Natural History 158:83-172.

Poyato-Ariza F J, López-Horgue MA, García-Garmilla F. 2000. A new early Cretaceous clupeomorph fish from the Arratia Valley, Basque Country, Spain. Cretaceous Research 21:571-585.

Polck MAR, Gallob V, Figueiredo FJ, Viana SM, Santos VSS, Queiroz Neto JV, Jahnert RJ. 2020. $\dagger$ Ellimma longipectoralis sp. nov. (Teleostei: Clupeomorpha: $\dagger$ Ellimmichthyiformes) from the Aptian of the Santos Basin, southeastern Brazil. Journal of South American Earth Sciences, https://doi.org/10.1016/j.jsames.2019.102318

Quan C, Fu QY, Shi GL, Liu YS, Li L, Liu XY, Jin JH. 2016. First Oligocene mummified plant Lagerstätte in the low latitudes of East Asia. Science China Earth Sciences DOI $10.1007 / \mathrm{s} 11430-015-5250-\mathrm{Z}$

Ronquist F, Huelsenbeck JP. 2003. MrBayes 3: Bayesian phylogenetic inference under mixed models. Bioinformatics 19:1572-1574.

Silva Santos R. 1990. Clupeiformes e Gonorhynchiformes do Cretáceo Inferior (Aptiano) da Formação Cabo, Nordeste do Brasil. Anais Academia Brasileira Ciências 62(3):261-268.

Silva Santos R. 1994. Ictiofáunula da Formação Codó, Cretáceo Inferior, com a descrição de um novo táxon - Codoichthys carnavalii (Pisces-Teleostei). Anais Academia Brasileira Ciencias 66:131-143.

Schaeffer B. 1947. Cretaceous and Tertiary actinopterygian fishes from Brazil. Bulletin of the American Museum of Natural History 89: 1-4. 
843 Signeux J. 1951. Notes paléoichthyologiques. V. Diplomystus dubertreti, une nouvelle espèce 844 du Sénonien du Liban. Bull. Mus. natl. Hist. natur., Paris 23 (2):692-693.

845 Signeux J. 1964. Gasteroclupea branisai, clupéidé nouveau du Crétacé Supérieur de Bolivie. 846 Bull Mus Natl Hist Nat. 36:291-297.

847

Shi G, Zhou Z, Xie Z. 2010. A new Cephalotaxus and associated epiphyllous fungi from the Oligocene of Guangxi, South China. Review Palaeobotany Palynology DOI 10.1016/j.revpalbo.2010.04.002

Shi G, Zhou Z, Xie Z. 2012. A new Oligocene Calocedrus from South China and its implications for transpacific floristic exchanges. American Journal of Botany 99: 108-120.

Shi GL, Xie ZM, Li HM. 2014. High diversity of Lauraceae from the Oligocene of Ningming, South China. Palaeoworld 23:336-356.

Sun A L. 1956. Paraclupea - a genus of double-armoured herrings from Chekiang. Acta Paleontologica Sinica 4:413-418.

Sychevskaya E K. 1986. Paleogene freshwater fish fauna of the USSR and Mongolia. Joint Soviet-Mongolian Paleontological Expedition, Transactions 29:1-157. (Russian with English summary)

Tang X. 1959. A new fossil fish from Linli, Hunan. Vertebrata PalAsiatica (in Chinese) 1:211213.

Uyeno T. 1979. Early Cretaceous freshwater fishes from northern Kyushu, Japan. I. Description of two new species of the clupeid genus Diplomystus. Bulletin of Kitakyushu Museum of Natural History 1:11-24.

Vernygora O, Murray AM. 2015. A new species of Armigatus (Clupeomorpha, Ellimmichthyiformes) from the Late Cretaceous of Morocco, and its phylogenetic 

relationships. Journal of Vertebrate Paleontology DOI 10.1080/02724634.2015.1031342.

867

Vernygora O, Murray AM. 2020. Morphological variation among the species of Armigatus (Teleostei, Clupeomorpha, Ellimmichthyiformes) and new material of Armigatus alticorpus from the Upper Cretaceous (Cenomanian) of Hakel, Lebanon. Cretaceous Research. https://doi.org/10.1016/j.cretres.2020.104601.

Vernygora O, Murray AM, Wilson MVH. 2016. A primitive clupeomorph from the Albian Loon River Formation (Northwest Territories, Canada). Canadian Journal of Earth Science 53:331-342.

Wang J K, Li G F, Wang J S. 1981. The early Tertiary fossil fishes from Sanshui and its adjacent basin, Guangdong (in Chinese). Palaeontologia Sinica (New Series C) 22:1-90.

Wang Q, Song Z, Chen Y, Shen S, Li ZY. 2014. Leaves and fruits of Bauhinia (Leguminosae, Caesalpinioideae, Cercideae) from the Oligocene Ningming Formation of Guangxi, South China and their biogeographic implications. BMC Evolutionary Biology 14:1-17.

Wang W, Chen G, Chen F, Kuang G. 2003. Tertiary palynostratigraphy of the Ningming basin, Guangxi. Journal of Stratigraphy 27:324-327. (Chinese with English abstract)

Woodward A S. 1895. On two deep-bodied species of the clupeoid genus Diplomystus. The Annals and Magazine of Natural History 15 (6):1-3.

Yabumoto Y. 1995. Correlation of the Early Cretaceous lacustrin beds between Kyushu of Japan and southeastern China on the basis of a comparison of the fish fossils. The Sixth Symposium on Mesozoic Terrestrial Ecosystems and Biota, Short Papers 23-28.

Yabumoto Y, Yang S-Y, Kim T-W. 2006. Early Cretaceous freshwater fishes from Janpan and Korea. Journal of the Society of Korea 22:119-132.

Zaragüeta-Bagils R. 2004. Basal clupeomorphs and ellimmichthyiform phylogeny. In Arratia G, 
889 Tintori A, eds. Mesozoic Fishes 3: Systematics, Paleoenvironments and Biodiversity.

890 München: Verlag Dr. Friedrich Pfeil, 391-404.

891 Zhang MM, Zhou JJ, Qing DR. 1985. Tertiary fish fauna from coastal region of Bohai Sea.

892 Academia Sinica, Institute of Vertebrate Paleontology and Paleoanthropology Memoirs $893 \quad 17: 1-60$.

894 Zhao Z. 1983. A new species of Anthracothere from Nanning Basin, Guangxi. Vertebrata

$895 \quad$ PalAsiatica 21:266-270. (Chinese with English abstract)

896 Zhao Z. 1993. New Anthracothere materials from the Paleogene of Guangxi. Vertebrata

897

PalAsiatica 31:13-190. (Chinese with English abstract) 


\section{Figure 1}

Map of the main localities of ellimmichthyiform fossils.

1. Ningming, 2. Nanning, Guangxi, 3. Kenli, Shandong, 4. Huadian, Jilin, 5. Xialiaohe Oilfield, Liaoning, 6. Linhai, Zhejiang, and 7. Anxi, Fujian, China; 8. northern Kyushu, Japan; 9. Namoura, 10. Hakel and Hajula, Mount Lebanon, and 11. Sahel Alma, Lebanon; 12. Ein Yabrud, Palestine; 13. Trieste and 14. Bolca Lagerstätte, Italy; 15. Kent, England; 16. Dalmatia, Croatia; 17. Basque-Cantabrian Basin, Spain; 18. Portugal; 19. Equatorial Guinea; 20. Kwango, Zaire; 21. Chotts Basin and 22. Gabès, Tunisia; 23. Jbel Tselfat, 24. Aoult, and 25. Jbel Oum Tkout, Morocco; 26. Sierra de Santa Bárbara and 27. La Puerta, Argentina; 28. Cayara and 29. Agua Clara, Bolivia; 30. Santa Barbara, Venezuela; 31. São Luís-Grajaú Basin, 32. Alagoas Basin, 33. Sergipe Basin, 34. Recôncavo Basin, and 35. Santos Basin, Brazil; 36. Chiapas and 37. Puebla, Mexico; 38. Wyoming, USA; 39, near Red Deer River, 40. south of Grand Prairie, and 41. Northwest Territories, Canada.

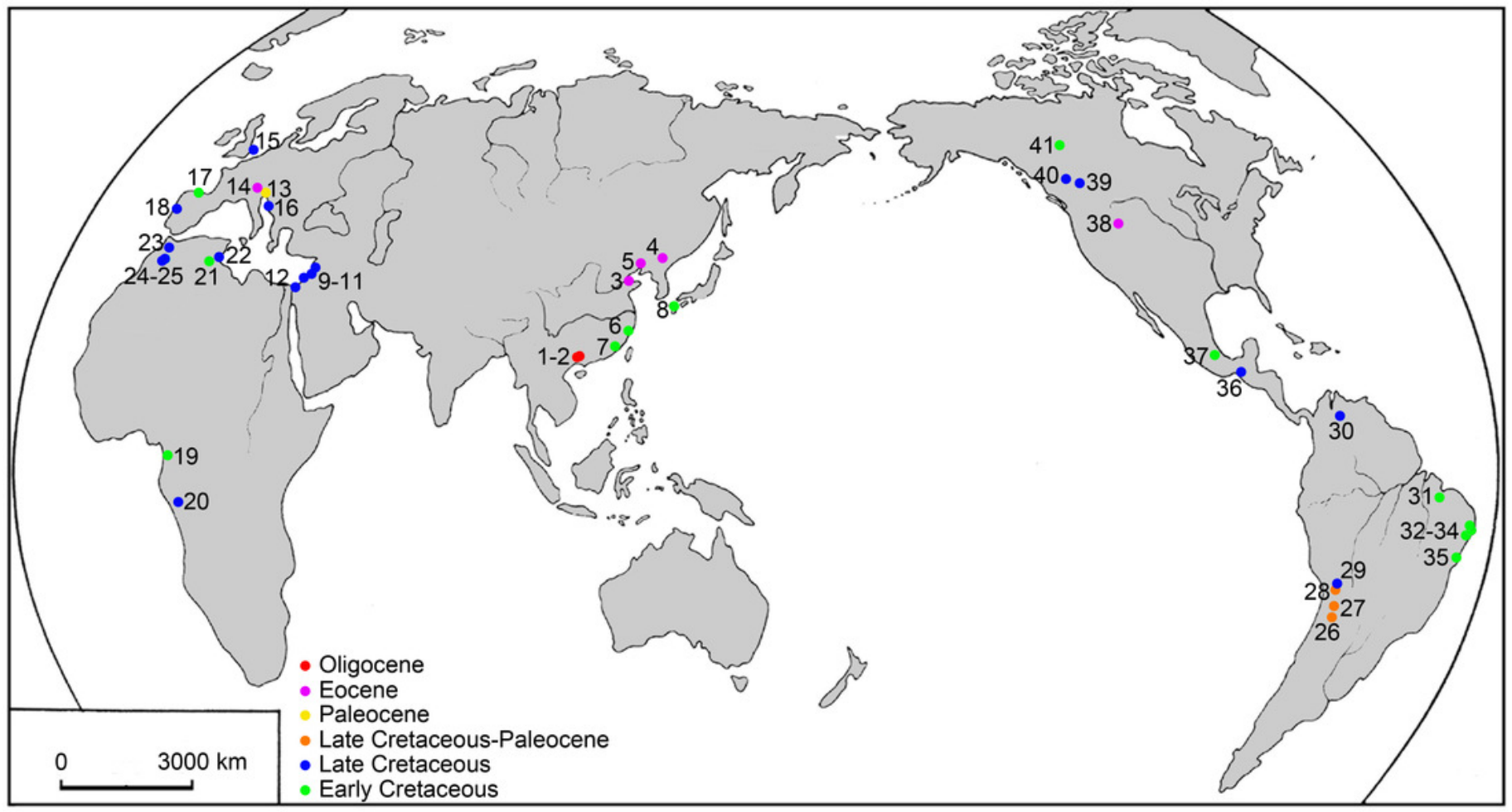


Figure 2

Guiclupea terminus, gen. et sp. nov.

A, and B, photograph of the holotype (NHMG 005532); C, close up of the complete predorsal scutes series maked by the black box in $\mathrm{A}$.




Figure 3

Guiclupea superstes, gen. et sp. nov

A, photograph of the NHMG 033659; B, tentative restoration mainly based on the holotype and paratypes.
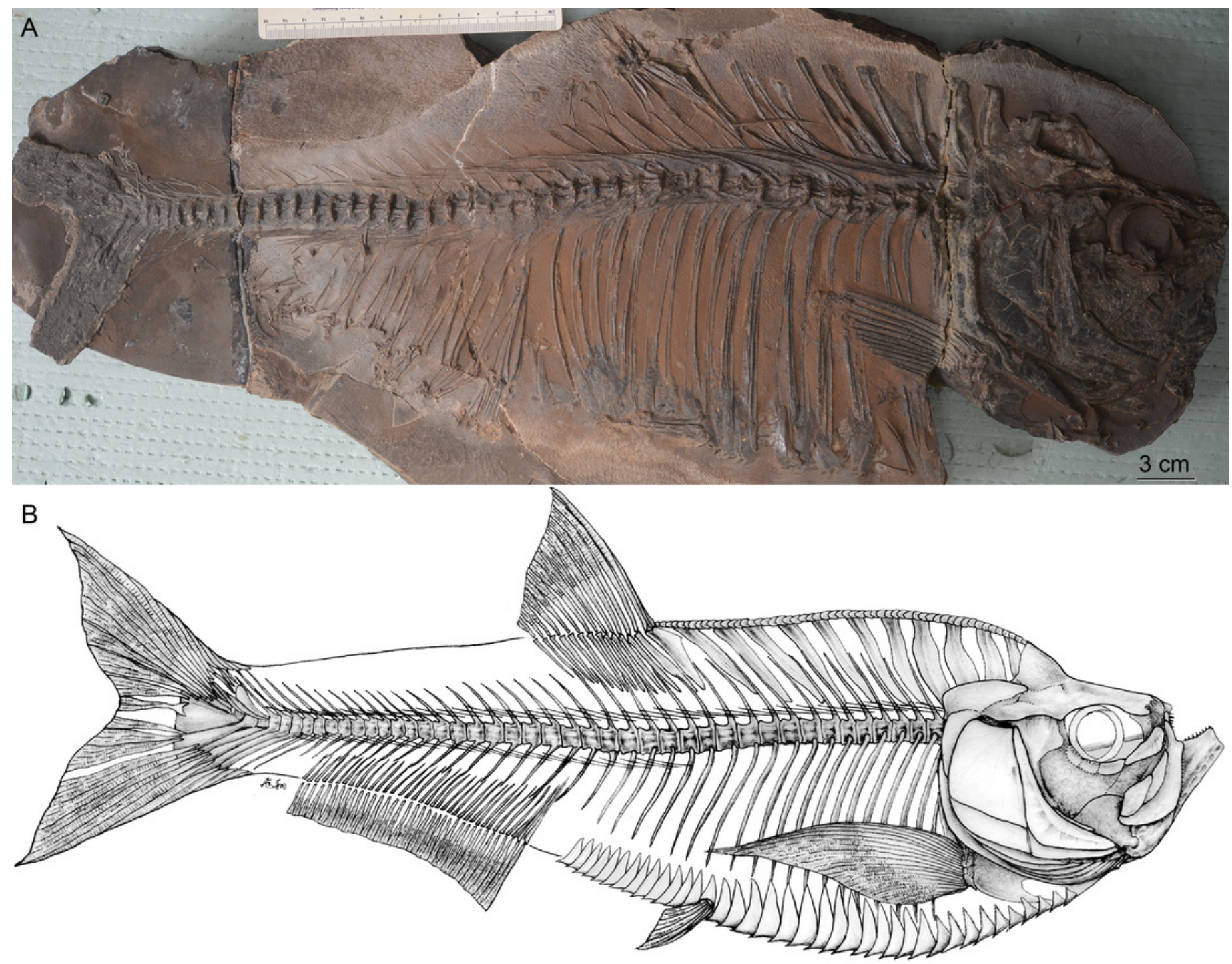


\section{Figure 4}

Guiclupea terminus, gen. et sp. nov.

A, photograph, and B, line drawing of the head in NHMG 033659. Anterior facing right. C, photograph of a left premaxilla, NHMG 033685; D, photograph of an incomplete dentary, NHMG 033682, showing the oral teeth; E, photograph of a dentary, NHMG 033683; F, photograph, showing anterior ceratohyal and entopterygoid in NHMG 033661; G, photograph, showing posterior ceratohyals in NHMG 033680. 

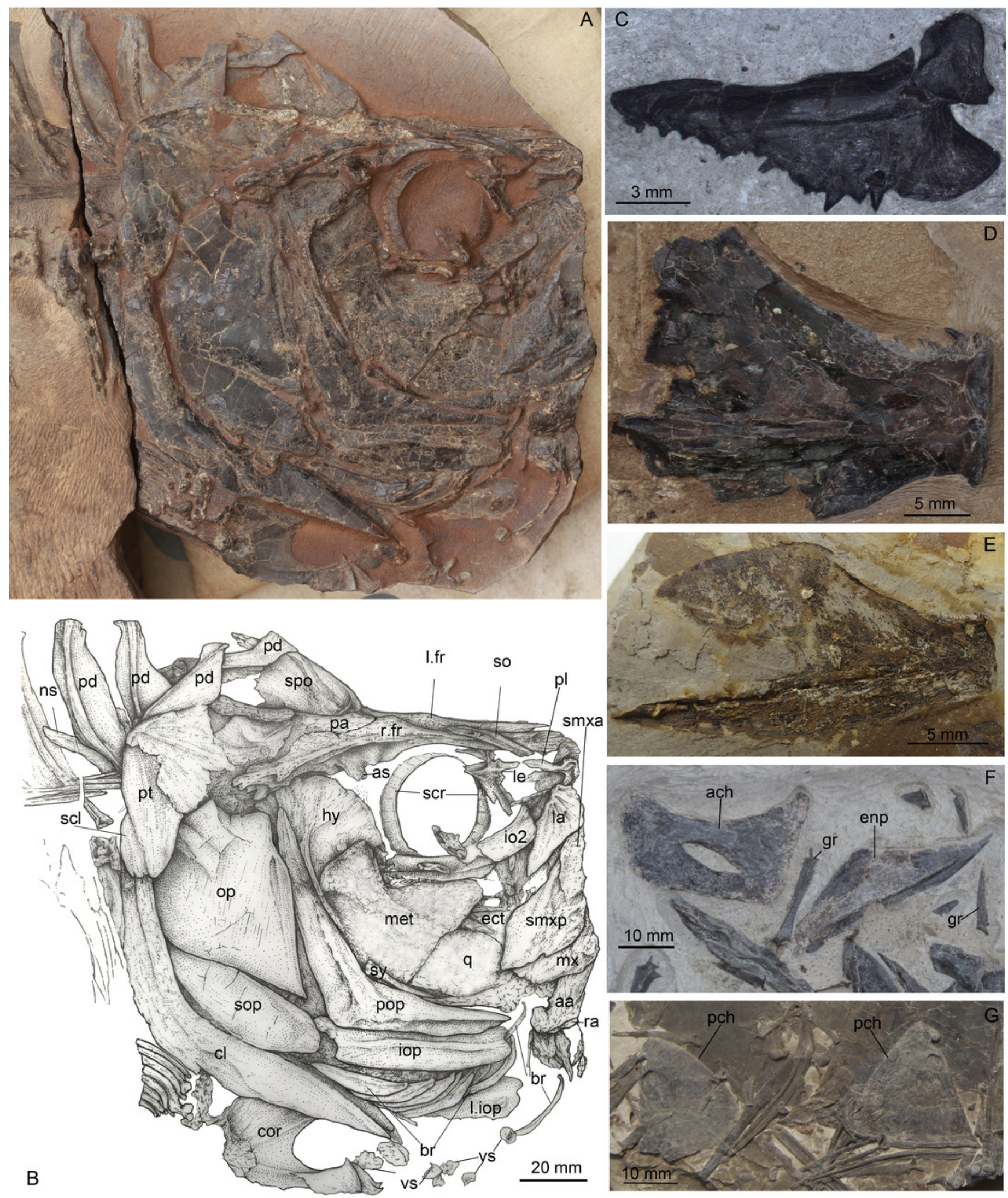


\section{Figure 5}

Guiclupea terminus, gen. et sp. nov.

photograph of the disarticular skull and anterior trunk bones of NHMG 033660.

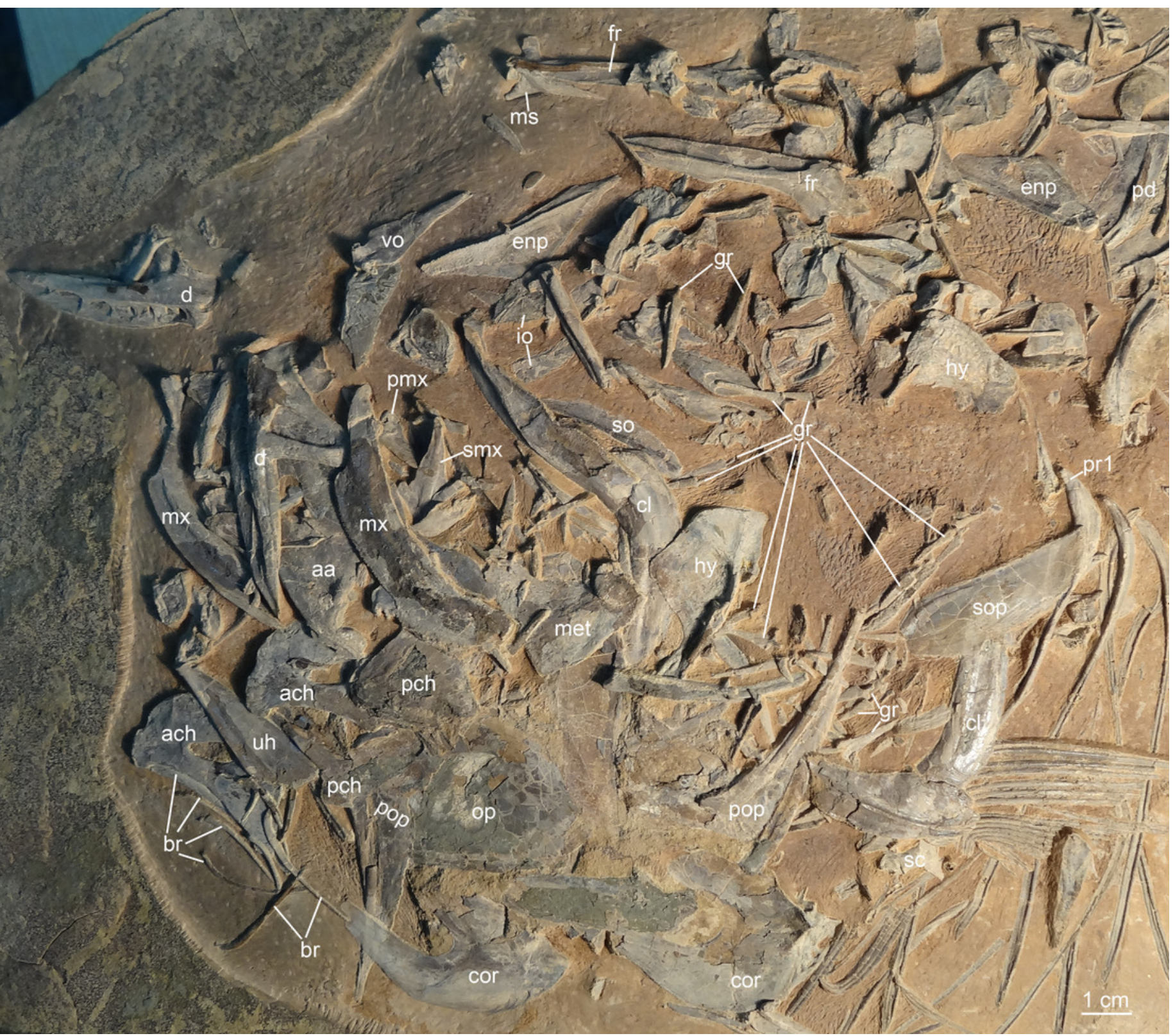


Figure 6

Guiclupea terminus, gen. et sp. nov.

A, photograph of NHMG 033658, B, and C, close up of the predorsal scutes in the black boxes of $B$ and $C$ in $A$, respectively.

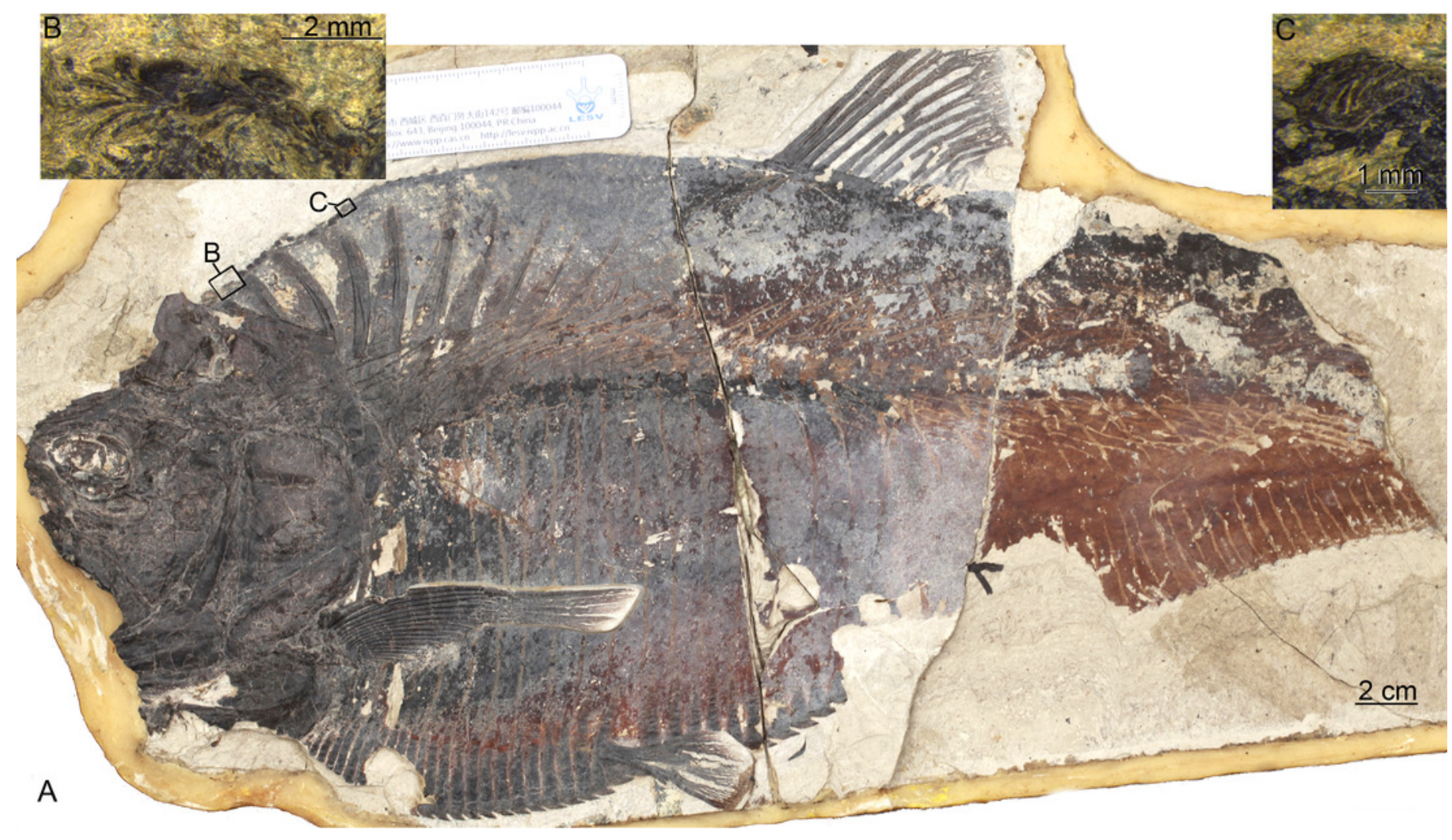


Figure 7

Guiclupea terminus, gen. et sp. nov.

A, photograph and B, line drawing of the caudal skeleton NHMG 011648. Anterior facing left. 

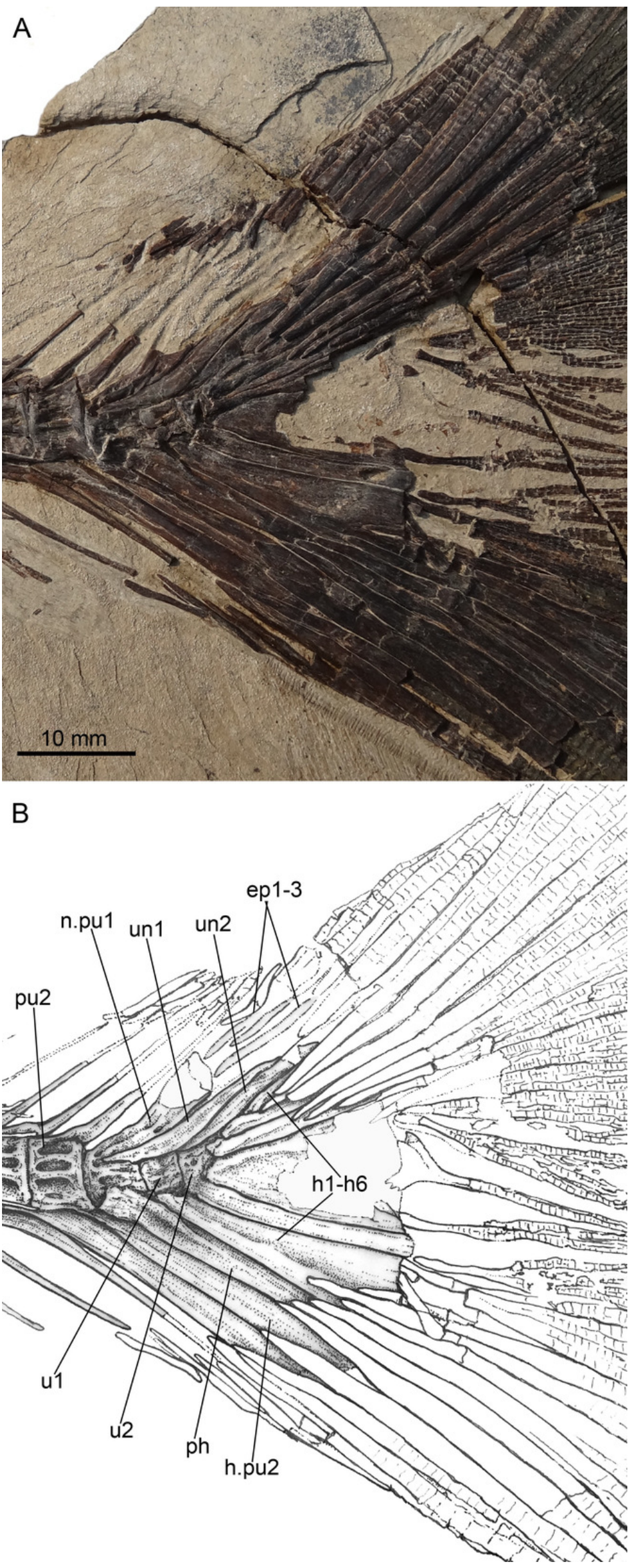
Figure 8

Strict consensus of most parsimonious trees

Strict consensus of most parsimonious trees retrieved in TNT 1.5 based on 55 morphological characters and 40 taxa, with Chanos chanos being used as outgroup taxa. Characters supporting each node are listed along corresponding branches. Characters above black spot have consistency index of 1 . Numbers at each node represents Bremer support/bootstrap values. Only bootstrap valies higher than $50 \%$ are shown on the tree. 

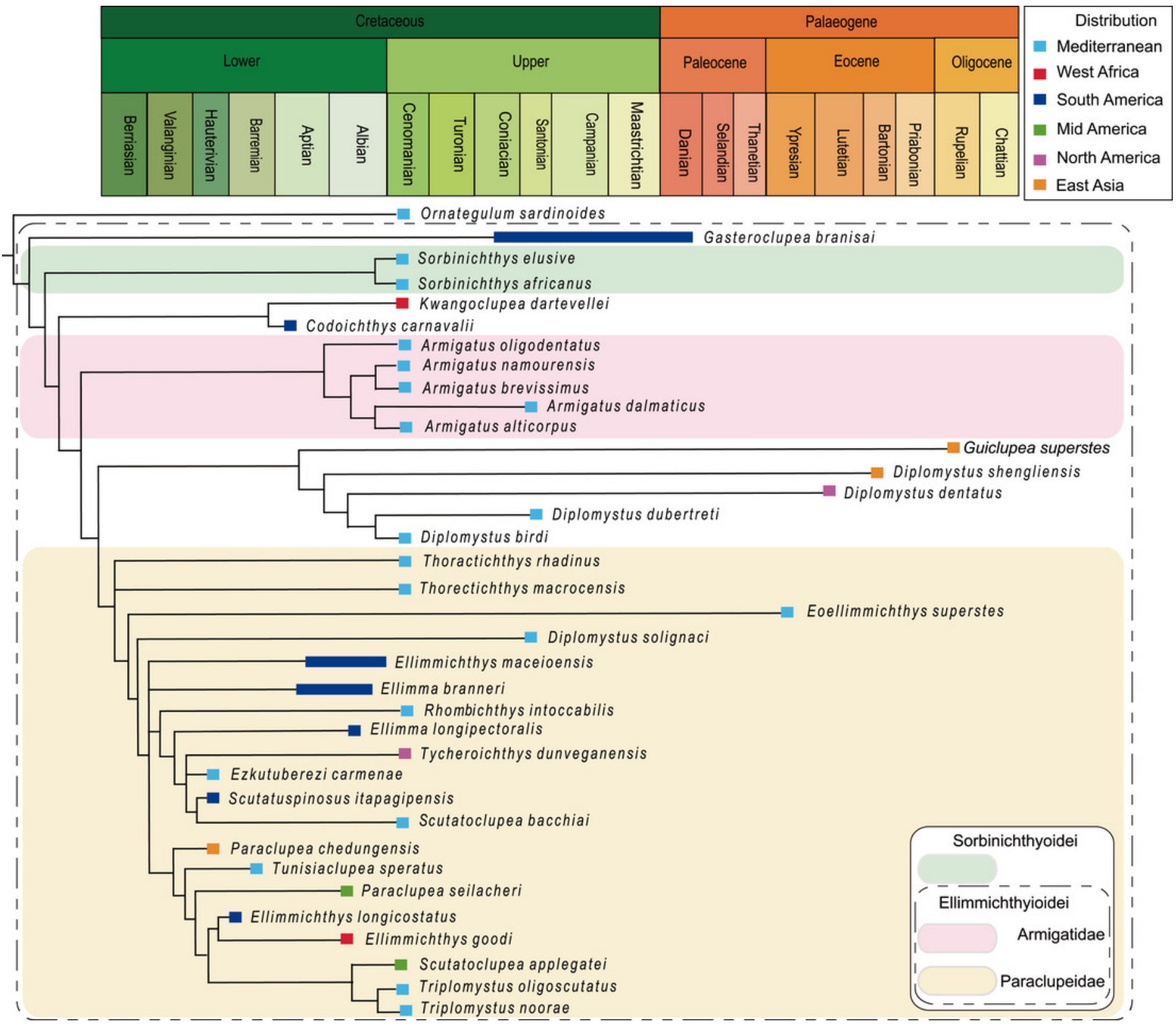
Figure 9

Cladogram

Cladogram resulting from Bayesian phylogenetic analyses based on 55 morphological characters and 40 taxa, with Chanos chanos used as outgroup taxon. The numbers at the internal nodes are the posterior probabilities of the corresponding clades. 


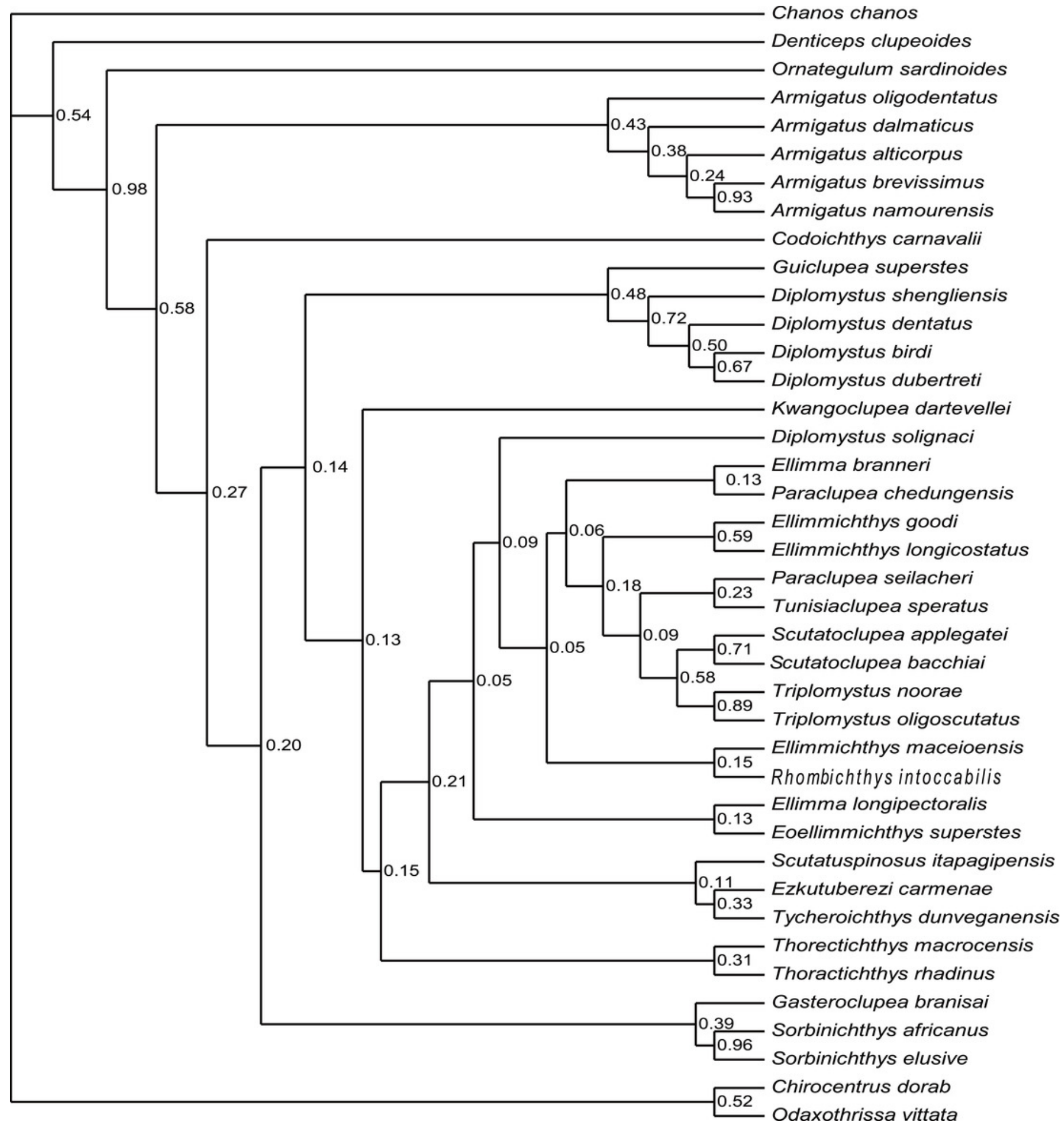




\section{Table 1 (on next page)}

\section{TABLE}

Measurements and counts for the specimens of the † Guiclupea superstes, gen. et sp. nov. Measurements are in millimeters. 
1 TABLE 1. Measurements and counts for the specimens of the †Guiclupea superstes, gen. et sp. 2 nov. Measurements are in millimeters.

3

\begin{tabular}{|c|c|c|c|c|}
\hline & 004929 & 005532 & 033658 & 033659 \\
\hline total length & & 526.0 & & $630+$ \\
\hline standard length (SL) & $502+*$ & 453.0 & $410+$ & $585+$ \\
\hline head length & 175 & 132.0 & & $140+$ \\
\hline head length/SL & & $29.1 \%$ & & \\
\hline head depth & 169.0 & 116.0 & & $165+$ \\
\hline body depth & 213 & 137.0 & 150 & 210 \\
\hline body depth/SL & & $30.2 \%$ & & \\
\hline predorsal length & 333.5 & 252.8 & & $310+$ \\
\hline predorsal length/SL & & $55.8 \%$ & & \\
\hline prepelvic length & 293.7 & 242.0 & & $260+$ \\
\hline prepelvic length/SL & & $53.4 \%$ & & \\
\hline preanal length & 387.0 & 309.3 & & $358+$ \\
\hline Preanal length/SL & & $68.3 \%$ & & \\
\hline dorsal fin rays & & Ii, 12 & at least 13 & \\
\hline anal fin rays & & $\sim 35$ & & \\
\hline pterygophores of anal fin & & $\sim 36$ & $29+$ & $22+$ \\
\hline pectoral fin rays & & at least 12 & 18 & $12+$ \\
\hline pelvic fin rays & & $5 \sim 6$ & $5 \sim 6$ & \\
\hline abdominal vertebrae & 20 & 22 & 20 & 20 \\
\hline caudal vertebrae (exclude u1, u2) & $12+$ & 23 & & 24 \\
\hline total vertebrae (exclude u1, u2) & $32+$ & 45 & & 44 \\
\hline predorsal bones & 10 & 10 or 11 & 10 & 10 \\
\hline abdominal scutes & at least 36 & $\sim 38$ & $35+$ & $27+$ \\
\hline pre-pelvic scutes & $\sim 24$ & $\sim 24$ & $\sim 24$ & $16+$ \\
\hline post-pelvic scutes & at least 12 & 14 & $11+$ & $11+$ \\
\hline pre-dorsal scutes & & 55 & $27+$ & \\
\hline pairs of ribs & 18 & 20 & 18 & 19 \\
\hline
\end{tabular}

4 *: "+" stand for the actual digital larger than this digital because of the specimen is incomplete or not well5 preserved. 